J. Dairy Sci. 92:5335-5352

doi:10.3168/jds.2009-2461

(c) American Dairy Science Association, 2009.

\title{
Invited review: Milk protein polymorphisms in cattle: Effect on animal breeding and human nutrition
}

\author{
A. M. Caroli, ${ }^{* 1}$ S. Chessa,† and G. J. Erhardtł \\ *Dipartimento di Scienze Biomediche e Biotecnologie, Università degli Studi di Brescia, Viale Europa 11, Brescia, 25123 Italy \\ †Dipartimento di Scienze e Tecnologie Veterinarie per la Sicurezza Alimentare, Università degli Studi di Milano, Via Trentacoste 2, Milano, \\ 20134 Italy \\ †Institut für Tierzucht und Haustiergenetik, Justus-Liebig-Universität, Ludwigstr. 21 b, 35390 Gießen, Germany
}

\section{ABSTRACT}

The 6 main milk proteins in cattle are encoded by highly polymorphic genes characterized by several nonsynonymous and synonymous mutations, with up to 47 protein variants identified. Such an extensive variation was used for linkage analysis with the description of the casein cluster more than $30 \mathrm{yr}$ ago and has been applied to animal breeding for several years. Casein haplotype effects on productive traits have been investigated considering information on the whole casein complex. Moreover, mutations within the noncoding sequences have been shown to affect the specific protein expression and, as a consequence, milk composition and cheesemaking. Milk protein variants are also a useful tool for breed characterization, diversity, and phylogenetic studies. In addition, they are involved in various aspects of human nutrition. First, the occurrence of alleles associated with a reduced content of different caseins might be exploited for the production of milk with particular nutritional qualities; that is, hypoallergenic milk. On the other hand, the frequency of these alleles can be decreased by selection of sires using simple DNA tests, thereby increasing the casein content in milk used for cheesemaking. Furthermore, the biological activity of peptides released from milk protein digestion can be affected by amino acid exchanges or deletions resulting from gene mutations. Finally, the gene-culture coevolution between cattle milk protein genes and human lactase genes, which has been recently highlighted, is impressive proof of the nonrandom occurrence of milk protein genetic variation over the centuries.

Key words: milk protein, cattle, genetic polymorphism

Received June 5, 2009

Accepted July 28, 2009.

${ }^{1}$ Corresponding author: caroli@med.unibs.it

\section{INTRODUCTION}

More than $95 \%$ of the proteins contained in ruminant milk are coded by 6 structural genes (Martin et al., 2002; Figure 1). The 4 casein genes are tightly linked in a $250-\mathrm{kb}$ cluster (Ferretti et al., 1990; Threadgill and Womack, 1990) mapped on chromosome 6 (Hayes et al., 1993; Popescu et al., 1996). In physical order, these genes are CSN1S1, CSN2, CSN1S2, and CSN3 and encode $\alpha_{\mathrm{s} 1}-\mathrm{CN}, \beta-\mathrm{CN}, \alpha_{\mathrm{s} 2}-\mathrm{CN}$, and $\kappa-\mathrm{CN}$, respectively. This gene cluster is also referred to as the $\mathrm{CN}$ locus (Martin et al., 2002) or super locus (Freyer et al., 1999). The 2 main whey proteins, $\alpha-\mathrm{LA}$ and $\beta-\mathrm{LG}$, are coded by $L A A$ and $L G B$ genes, mapped on chromosomes 5 (Hayes et al., 1993) and 11 (Hayes and Petit, 1993), respectively.

Among ruminants, milk protein genes have been thoroughly investigated in cattle and goats, and a noticeable genetic variation has been identified and characterized. The importance of such an extensive genetic variation for animal breeding is mainly the consequence of the effects of milk protein variants on milk composition and cheesemaking properties (reviewed by Grosclaude, 1988; Di Stasio and Mariani, 2000; Martin et al., 2002). These effects are related to functional modifications of the protein, mainly AA exchanges or deletions, which affect the biological properties of the coded protein. In addition, milk protein variants were used for breed characterization (Moazami-Goudarzi et al., 2001; Ceriotti et al., 2004a), biodiversity investigations (Lien et al., 1999; Mahé et al., 1999), and evolution studies on both animal resources and milk protein genes (Jann et al., 2004; Ibeagha-Awemu et al., 2007). For such studies, an interesting approach is to consider the whole CN haplotype instead of individual genes coding for the 4 caseins (Beja-Pereira et al., 2002).

In this review, we will concentrate our attention on the bovine species, aiming both to emphasize the pioneer work and exhaustive reviews that have already been carried out on the subject in the past $30 \mathrm{yr}$ and to elucidate some of the main aspects affecting animal 


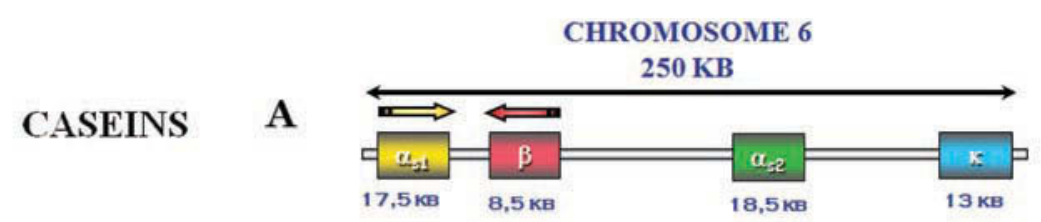

B
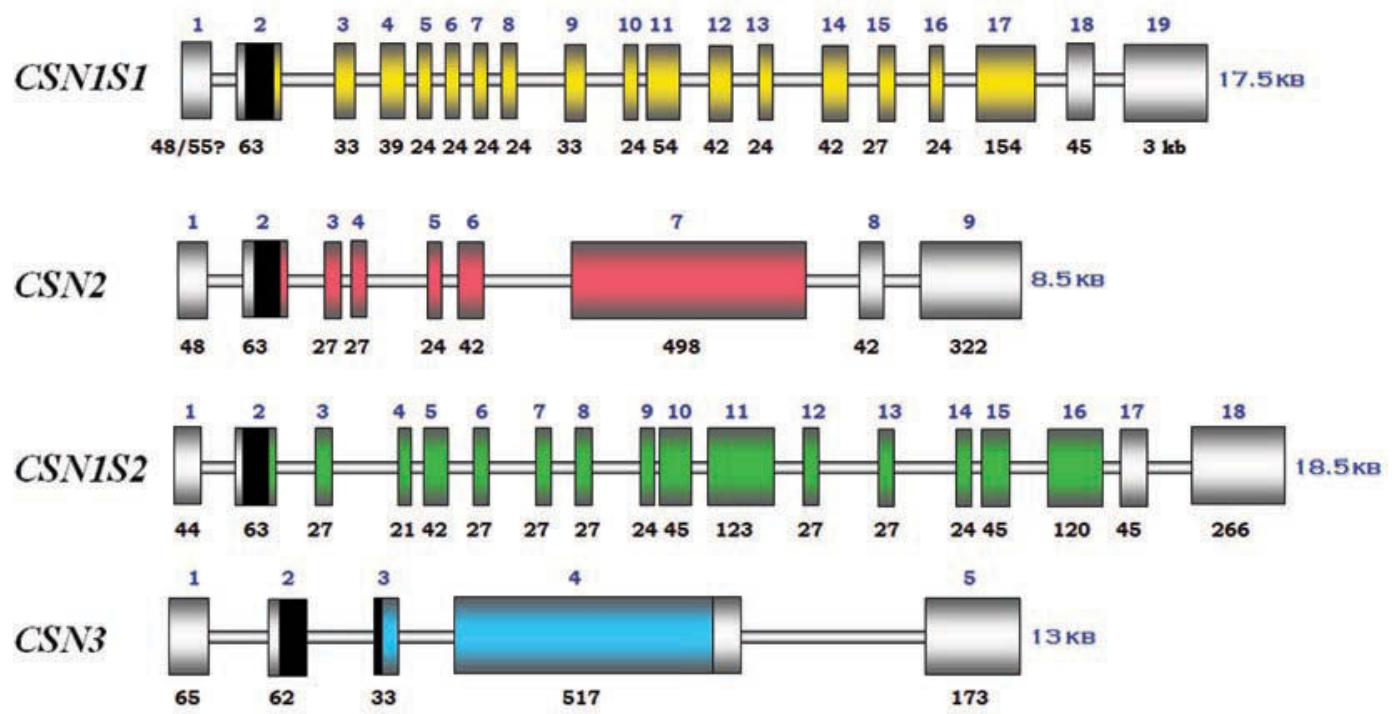

CHROMOSOME 5

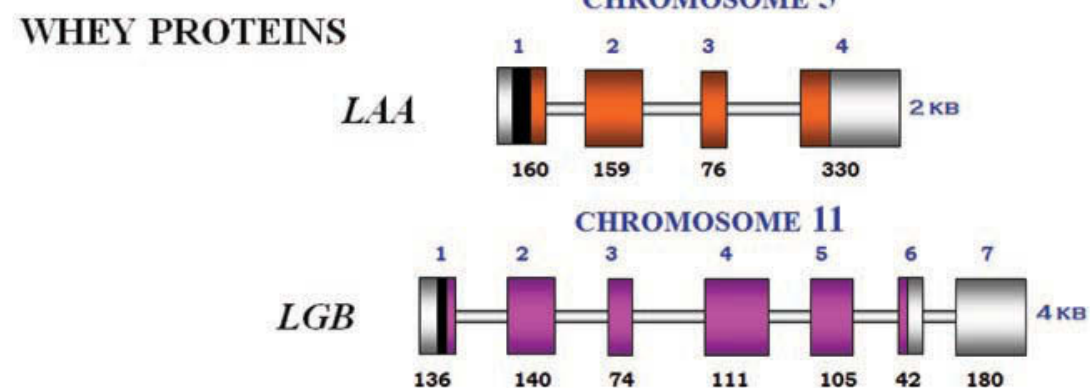

Figure 1. Structural organization of the transcription units encoding the 6 main milk proteins. Caseins: $\alpha_{\mathrm{s} 1}$-CN (CSN1S1), $\beta-\mathrm{CN}$ (CSN2), $\alpha_{\mathrm{s} 2}$-CN (CSN1S2), and $\kappa-\mathrm{CN}(C S N 3)$. Whey proteins: $\alpha$-LA $(L A A)$ and $\beta$-LG $(L G B)$. A) Genomic organization of the bovine casein locus. B) Structural organization of the 6 milk protein transcription units. Open bars represent introns; exons are depicted by large, gray $\left(5^{\prime}\right.$ and $3^{\prime}$ untranslated regions), black (part of exon encoding the signal peptide), and colored (exons and part of exons encoding matured proteins) boxes. Size of exons is given, in base pairs, under each exon with its number indicated on the top (modified from Martin et al., 2002).

breeding and human nutrition, with special focus on innovative scientific approaches.

\section{BOVINE MILK PROTEIN VARIANTS}

Studies on milk protein genetic variability started more than 50 yr ago by detecting bovine $\beta$-LG main variants (Aschaffenburg and Drewry, 1957) and intensified during the following years, discovering polymorphisms with important differences among bovine species and breeds (reviewed by Formaggioni et al., 1999). Genetic variants can result from SNP, as well as nucleotide (nt) deletions or insertions. A recent review of milk protein nomenclature (Farrell et al., 2004) indicated $8 \alpha_{\mathrm{s} 1}-\mathrm{CN}$ $(A, B, C, D, E, F, G, H), 4 \alpha_{\mathrm{s}^{2}} \mathrm{CN}(A, B, C, D), 12$ $\beta$-CN $\left(A^{1}, A^{2}, A^{3}, B, C, D, E, F, G, H^{1}, H^{2}, I\right), 11$

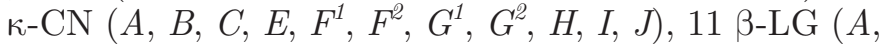
$B, C, D, E, F, G, H, I, J, W)$, and $3 \alpha$-LA $(A, B, C)$ variants in the Bos genus. The nomenclature is unified for the 4 species of Bos genus mainly considered in cattle milk protein studies; that is, Bos taurus (taurine bovine), Bos indicus (zebu), Bos grunniens (yak), and Bos javanicus (banteng of Bali). Only protein polymorphisms are considered in this review, namely mutations 
modifying the AA sequence of the coded protein, with the exception of $C S N 1 S 1^{*} G$ differing from $C S N 1 S 1^{*} B$ for a lower protein expression (Rando et al., 1998).

In addition to the review by Farrell et al. (2004), a novel $\alpha_{\mathrm{s} 1}$ CN protein variant, named $C S N 1 S 1^{*} I$, was recently characterized (Lühken et al., 2009). An A > T SNP substitution in exon 11 leads to the substitution Glu > Asp at AA position 84 of the mature protein. Lühken et al. (2009) postulated that $C S N 1 S 1^{*} I$ originated within Bos indicus and spread to Bos taurus subsequently. Thus, the number of $\alpha_{\mathrm{s} 1} \mathrm{CN}$ protein variants increases to 9 . The characterization of $\alpha_{\mathrm{s}^{2}} \mathrm{CN}^{*} B$ has also been performed, and a $\mathrm{C}>\mathrm{T}$ exchange has been identified in the 17th nt of exon 3, leading to the Ser $>$ Phe substitution in the eighth amino acid of the mature protein (Ibeagha-Awemu et al., 2007).

As for CSN3, the $B^{2}$ variant characterized by Gorodetskiı̌ and Kaledin (1987) can be added to the list of Farrell et al. (2004). This variant is available on Swiss-Prot (no. P02668). More details on $C S N 3{ }^{*} C$ and $\operatorname{CSN}^{*} G^{2}$, as per nomenclature of Farrell et al. (2004), are given in the following.

Conflicting data have been reported about $\operatorname{CSN} 3^{*} C$, which was first described in the Grey Alpine (Di Stasio and Merlin, 1979) as a variant migrating faster than CSN3* $^{*}$ by alkaline electrophoresis. Mariani (1983) found a similar migrating variant in the Italian Brown and suggested it was the same as that in the Grey Alpine. However, no characterization of the variant was carried out in either breed. Later, Seibert et al. (1987) named $C S N 3^{*} D$, a variant migrating in the same position as $C S N{ }^{*} A$ by alkaline electrophoresis but showing an intermediate position between $C S N 3^{*} A$ and $C S N 3^{*} B$ by isoelectrofocusing (IEF). The correspondence of such a variant with $C S N 3^{*} C$ was shown by IEF (Krause et al., 1988); thus, $C S N 3^{*} D$ disappeared from cattle milk protein nomenclature, not taking into account the different migration observed by alkaline electrophoresis. Miranda et al. (1993), following the new nomenclature, characterized $C S N 3^{*} C$, namely the old $C S N 3^{*} D$, as a counterpart of $C S N 3^{*} B$. An unassigned $C S N 3$ sequence DNA (GenBank No. AJ619772) demonstrates the existence of a variant carrying $\mathrm{His}_{97}$, as $\mathrm{CSN}^{*} \mathrm{C}$ does, that is identical to $C S N 3^{*} A$ at the other positions. The variant was found in Italian Brown cattle and migrated by alkaline gel faster than $\operatorname{CSN}^{*} A$ but at an intermediate position between $A$ and $B$ by IEF (A. M. Caroli; unpublished results). These data clearly indicate the existence of 2 variants carrying $\mathrm{His}_{97}$, which are the counterparts of $C S N 3^{*} B$ and $C S N 3^{*} A$, respectively. We would propose to maintain the name $C S N 3{ }^{*} C$ for the former and to give the latter the name $C S N 3^{*} D$, which is actually missing in the Bos genus nomenclature.
The $C S N 3^{*} G^{2}$ variant, first described in the yak by Sulimova et al. (1996), was recently confirmed by Prinzenberg et al. (2008) in the same species in which at least 2 yak-specific DNA sequences were found. All yak had nt sequences coding for Thr in AA position 136 (identical to bovine $C S N 3^{*} A$ ) and Ala in position 148 (identical to bovine $C S N 3^{*} B$ ). A 12-bp insertion in the coding region, representing a repeated nt and AA motif, was found in one allele, as well as differences in the stop codon sequences. The loss of the insertion might have led to the ancestral $C S N 3$ allele from which all currently known variants of CSN3 in the Bos genus evolved. In Bos taurus, a further CSN3 allele was found that coded for $\mathrm{Thr}_{136}$ and $\mathrm{Ala}_{148}$ (Chessa et al., 2007). This variant, which can be considered to be the wild type for the Bos genus, was tentatively named $C S N 3^{*} W$. The exact correspondence with $C S N 3^{*} G^{2}$ should be verified for the synonymous variations identified in the yak. In addition, Chen et al. (2008) found a CSN3 intragenic haplotype in the gayal (Bos frontalis) and zebu, differing from $C S N 3^{*} B$ for the occurrence of $\operatorname{Thr}_{136}$ instead of $\mathrm{Ile}_{136}$ and showing a close phylogenetic relationship with the banteng, gaur, and yak. In the latter, a $\mathrm{G}>$ C SNP substitution resulting in an AA substitution from $\operatorname{Arg}_{121}$ to $\mathrm{PrO}_{121}$ of the mature protein was also found (Bai et al., 2008). These data highlight the possible need to introduce separate nomenclature for milk protein variants, which can differ greatly among species within the Bos genus.

\section{GENOTYPING SYSTEMS}

Genetic variation can be detected at the phenotypic level by different protein identification techniques (i.e., electrophoresis, IEF, chromatography). The electrophoretic and isoelectrophoretic techniques, mainly used for routine typing at the protein level, only allow detection of genetic variation resulting in different electrophoretic or isoelectrophoretic mobility, such as AA exchanges altering the electric charge or the isoelectric point of the protein. For the screening of breeds and populations at the phenotypic level, IEF is still the most effective method and should be recommended for typing animals reared on continents where breed characterization using milk protein genes is still limited (e.g., Africa and Asia). For biodiversity studies, and if milk is available, typing at the protein level by IEF is recommended instead of analyzing just one milk protein at the DNA level because the method is cheap and fast and gives a simultaneous picture of the phenotype expression of the 6 main milk protein genes (Erhardt and Eggen, 1990). After this phenotypic screening, more detailed studies might be carried out at the DNA level for a wider scan 
Table 1. Position within the gene and mature protein of the CSN1S1 genetic variants in Bos genus ${ }^{1}$

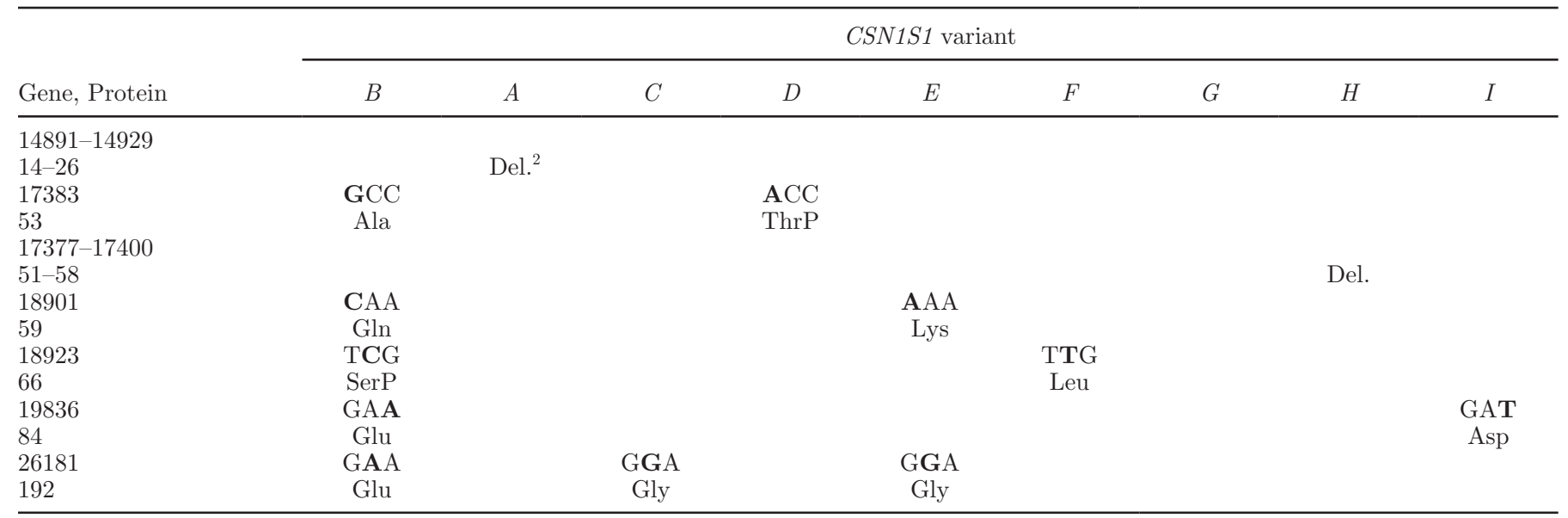

${ }^{1}$ The reference sequence is GenBank No. X59856, corresponding to the $C S N 1 S 1^{*} B$ allele. Nonsynonymous mutations are bolded within each codon. CSN $1 S 1^{*} E$ was found only in Bos grunniens.

${ }^{2}$ Del. $=$ Deleted

of the chromosome regions coding for the respective milk proteins.

Certainly, DNA analysis has given a new impulse to investigations of bovine milk protein polymorphisms, allowing the identification of known protein variants at the genome level by different techniques, such as PCR-RFLP for CSN3 (Damiani et al., 1990) and LGB typing (Medrano and Aguilar-Cordova, 1990), direct sequencing for CSN3 (Schlieben et al., 1991), allelespecific-PCR for CSN2 (Damiani et al., 1992) and CSN1S1 (David and Deutch, 1992), and PCR-singlestrand conformation polymorphism for CSN2 (Barroso et al., 1999) and CSN1S1 typing (Jann et al., 2002a). In addition, further nt mutations were identified at the DNA level that either modify the protein sequence (i.e., CSN2*I; Jann et al., 2002b), or result in synonymous protein variants because the nt substitution within the codon does not modify the correspondent AA. This is the case with $C S N 3^{*} A 1$ (Damiani et al., 1990) and $\operatorname{CSN}^{*}{ }^{*}{ }^{I}$ (Prinzenberg et al., 1999), both sharing the protein sequence with $\operatorname{CSN}^{*} A$, as well as CSN2* $^{*} A^{2}$ (Ceriotti et al., 2004a), which codes for the same protein as $C S N 2^{*} A^{2}$. Tables $1,2,3,4,5$, and 6 show the main milk protein variants that have been identified, using the nomenclature proposed by Farrell et al. (2004) and including the synonymous variant CSN3* $A^{I}$ because of its presence in many Bos indicus breeds (Jann et al., 2004). Table 7 combines the available information on the distribution and discovery of the genetic variants reported. Although the number of genetic variants identified and characterized in the Bos genus is very large, only a few variants (12 of 53) are widely distributed in Bos taurus and Bos indicus, 34 are less common or rare in these 2 species, and 7 occur only in Bos grunniens and/or Bos javanicus. This can set the priority of typing particular alleles based on the species and breed of interest.

Typing at the DNA level does not require the gene product, which renders feasible the genotyping of males and nonlactating females. Nevertheless, DNA extracted from milk somatic cells can also be used for the molecular analyses (Chessa et al., 2007), taking advantage of easier sampling of cows recorded for milk production.

Milk protein polymorphisms can provide useful information for identity control within official milk recording systems by analyzing individual milk by IEF (Erhardt and Senft, 1991). They can also be used as genetic markers for parentage testing. For the latter, application of high-throughput assays such as the microarray technology (Chessa et al., 2007) can lead to wide-scale animal genotyping at several SNP within the milk protein genes. In addition, the possibility of using particular milk protein variants to trace the origin of typical products derived from local breeds could be further investigated in light of encouraging results already obtained in goats (Ceriotti et al., 2004b).

\section{MILK PROTEIN VARIANTS AND CHEESEMAKING PROPERTIES}

One of the most striking effects of the milk protein polymorphisms on traits with economic interest is their relation with cheesemaking properties of milk; this effect has been mainly investigated in cattle (reviewed by Di Stasio and Mariani, 2000). Studies were conducted in Italy in the 1970s (i.e., Losi et al., 1973; Mariani et al., 1976), many of them focusing on the effects of $\kappa$-CN on the rheological quality of milk. The $\kappa$-CN, located predominantly on the casein micelle surface, is the specific substrate of the chymosin, the hydrolytic 
Table 2. Position within the gene and mature protein of the CSN2 genetic variants in Bos genus ${ }^{1}$

\begin{tabular}{|c|c|c|c|c|c|c|c|c|c|c|c|c|}
\hline Gene, Protein & \multicolumn{12}{|c|}{ CSN2 variant ${ }^{2}$} \\
\hline $4647-4648$ & AGC & & & & & $?^{3}$ & & & & & & \\
\hline 6562 & CGC & & & & & & & & & TGC & & \\
\hline 25 & Arg & & & & & & & & & Cys & & \\
\hline $6684-6686$ & AGT & & & & $\mathrm{AGT}$ & & & & & & & \\
\hline 6690 & GAA & & & & AAA & & & & & & & \\
\hline 37 & Glu & & & & Lys & & & & & & & \\
\hline 8101 & CAT & $\mathrm{CCT}$ & $\mathrm{CCT}$ & & & $\mathrm{CCT}$ & $\mathrm{CCT}$ & & & $?$ & $\mathrm{CCT}$ & $\mathrm{CCT}$ \\
\hline 67 & His & Pro & Pro & & & Pro & Pro & & & $?$ & Pro & Pro \\
\hline 8115 & CAA & & & & & & & & & & GAA & \\
\hline 72 & Gln & & & & & & & & & & Glu & \\
\hline 106 & His & & Gln & & & & & & & & & \\
\hline 8267 & $\mathrm{AGC}$ & & & AGG & & & & & & & & \\
\hline 122 & Ser & & & Arg & & & & & & & & \\
\hline $8311-8314^{4}$ & 4 & & & & & & & & 4 & & & \\
\hline $137-138^{4}$ & Pro & & & & & & & & Leu & & & \\
\hline 8356 & $\mathrm{CCT}$ & & & & & & & $\mathrm{CTT}$ & & & & \\
\hline 152 & Pro & & & & & & & Leu & & & & \\
\hline$? ?^{5}$ & $? ?$ & & & & & & & & & & $? ?$ & \\
\hline$? ?$ & Gln & & & & & & & & & & Glu & \\
\hline
\end{tabular}

${ }^{1}$ The reference sequence is GenBank No. X14711, corresponding to the $\operatorname{CSN}^{*}{ }^{1}$ allele. Nonsynonymous mutations are bolded within each codon. $C S N 2{ }^{*} D$ was found only in Bos indicus.

${ }^{2} H^{1}=\mathrm{H}$ of Han et al. (2000); $H^{2}=\mathrm{H}$ of Senocq et al. (2002).

${ }^{3} ?=$ Information not available.

${ }^{4}$ At position 137-138, a Pro-Leu inversion is controversial depending on the sequences (Farrell et al., 2004).

${ }^{5} ? ?=$ Substitution of Gln to Glu is described between residues 114-169 (Senocq et al., 2002).

Table 3. Position within the gene and mature protein of the CSN1S2 genetic variants in Bos genus ${ }^{1}$

\begin{tabular}{|c|c|c|c|c|}
\hline \multirow[b]{2}{*}{ Gene, Protein } & \multicolumn{4}{|c|}{ CSN1S2 variant } \\
\hline & $A$ & $B$ & $C$ & $D$ \\
\hline 6227 & $\mathrm{TCC}$ & TTC & & \\
\hline 8 & Ser & Phe & & \\
\hline 7568 & GAG & & GGG & \\
\hline 33 & Glu & & Gly & \\
\hline 8401 & GCA & & $\mathrm{ACA}$ & \\
\hline 47 & Ala & & Thr & \\
\hline 8853-8879 & & & & \\
\hline $51-59$ & & & & Del. $^{2}$ \\
\hline 8879 & GAG & & & GAT \\
\hline 59 & Glu & & & $(\mathrm{Asp}) \mathrm{-}^{3}$ \\
\hline 11018 & $\mathrm{ACC}$ & & ATC & \\
\hline 130 & Thr & & Ile & \\
\hline
\end{tabular}

${ }^{1}$ The reference sequence is GenBank No. M94327, corresponding to the $C S N 1 S 2^{*} A$ allele. Nonsynonymous mutations are bolded within each codon. $C S N 1 S 2{ }^{*} C$ was found only in Bos grunniens.

${ }^{2}$ Del. $=$ Deleted.

${ }^{3}-=$ Deleted within the protein, but the gene sequence changed. 
activity of which splits the $\kappa-\mathrm{CN}$ into the insoluble para-k-CN (amino acid 1-105) and the soluble caseinomacropeptide (CMP: amino acid 106-171). This is a crucial process for the production of cheese but also for the nutrition of suckling calves (Mercier et al., 1973). Important physiological functions such as increasing digestion efficiency (Mercier et al., 1976) and antibacterial activity (Malkoski et al., 2001) were ascribed in particular to CMP.

It is well known that milk with the $C S N 3^{*} B$ variant reacts more promptly with rennet and has a rennet coagulation time significantly shorter than milk with $\operatorname{CSN}^{*} * A$, whereas milk from heterozygous cows shows an intermediate behavior (Losi et al., 1973). Differences in the micelle stability that occur between the 2 genetic variants $C S S^{*} A$ and $C S N 3^{*} B$ are strictly connected to the micelle size and the glycosylation degree of the protein itself (Di Stasio and Mariani, 2000). Nevertheless, less-common CSN3 alleles might affect milk rheological properties, too. The constant monitoring of milk protein variation in different breeds of cattle is an essential practice aiming to avoid an increase in frequencies of mutations with unfavorable effects on cheesemaking. An example of a rare allele with a negative effect on rheological traits is $C \operatorname{SN} 3^{*} G$, identified in the Pinzgauer breed and associated with more unfavorable coagulation properties than $C S N 3^{*} A$ (Erhardt et al., 1997). Similarly, in the Italian Friesian, a negative effect of the $C S N 3^{*} E$ variant was detected on milk clotting traits (Caroli et al., 2000). Although $\kappa$-CN is a crucial element in renneting, interactions with the other milk protein systems have to be taken into account, in particular, $\beta$-CN and $\beta$-LG. In general, $C S N 2{ }^{*} B$ and $L G B^{*} B$ were found to be more favorable for rennet coagulation and the cheesemaking quality of milk (Di Stasio and Mariani, 2000). Composite CN genotypes (Aleandri et al., 1990; Comin et al., 2008) were also considered because of the tight genetic linkage among the CN genes. In Italian Holsteins, Comin et al. (2008) found CSN3 and CSN2 to be strongly associated with milk coagulation traits and milk and protein yields, respectively, and proposed the composite genotypes at both genes to be the most appropriate criterion for selection decisions. For coagulation time and curd firmness, the best CSN2-CSN3 composite genotypes were those with at least one $B$ allele at both loci.

Table 4. Position within the gene and mature protein of the CSN3 genetic variants in Bos genus ${ }^{1}$

\begin{tabular}{|c|c|c|c|c|c|c|c|c|c|c|c|c|c|c|}
\hline Gene, Protein & \multicolumn{14}{|c|}{ CSN3 variant $^{2}$} \\
\hline 12690 & $\mathrm{CGC}$ & & & & & & & & $\mathrm{CAC}$ & & & & & \\
\hline 12940 & $\mathrm{ACT}$ & & & $\mathrm{ACC}$ & & & & & & & & & & \\
\hline 93 & Thr & & & Thr & & & & & & & & & & \\
\hline 12950 & CGT & & & & & & & & & TGT & & & & \\
\hline 12971 & TCA & & & & & & & & & & & & GCA & \\
\hline 104 & Ser & & & & & & & & & & & & Ala & \\
\hline 13065 & $\mathrm{ACC}$ & & & & & & & & & ATC & & ATC & & \\
\hline 135 & Thr & & & & & & & & & Ile & & Ile & & \\
\hline 13068 & $\mathrm{ACC}$ & & ATC & ATC & ATC & & & & & & & & & ATC \\
\hline 136 & Thr & & Ile & Ile & Ile & & & & & & & & & Ile \\
\hline 150 & Pro & & & & & & & & & & & & & \\
\hline 13119 & $\mathrm{ATT}$ & & & $\mathrm{ACT}$ & & & & & & & & & & \\
\hline 153 & Ile & & & Thr & & & & & & & & & & \\
\hline 13124 & AGC & & & & & & GGC & & & & & & & $?^{3}$ \\
\hline 155 & Ser & & & & & & Gly & & & & & & & Arg \\
\hline 13162 & $\mathrm{AC} T$ & & & $\mathrm{ACC}$ & & & & & & & $\mathrm{ACC}$ & & & \\
\hline 167 & Thr & & & & & & & & & & & & & \\
\hline 13165 & $\mathrm{GC} A$ & & $\mathrm{GC} G$ & $\mathrm{GC} G$ & $\mathrm{GC} G$ & $?$ & & & & & $\mathrm{GC} G$ & & & \\
\hline 168 & Ala & & & & & & & & & & & & & \\
\hline
\end{tabular}

${ }^{1}$ The reference sequence is GenBank No. AY380228, corresponding to the $C S N 3^{*} A$ allele. Nonsynonymous and synonymous mutations are respectively bolded and in italics within each codon.

${ }^{2} F^{1}=\mathrm{F}$ of Sulimova et al. (1992); $F^{2}=\mathrm{F}$ of Prinzenberg et al. (1996), GenBank no. AF123250; $G^{1}=G$ of Erhardt (1996), Prinzenberg et al. (1996), GenBank no. AF123251; $G^{2}=G$ of Sulimova et al. (1996); $D=$ GenBank No. AJ619772.

${ }^{3}$ ? = Information not available. 


\section{MILK PROTEIN EVOLUTION}

Interspecies comparisons of cDNA and milk protein genes have confirmed their high rate of evolution, but the overall gene organization has been conserved (Mercier and Vilotte, 1993). The CN genes appear to be a rapidly evolving family, presumably because of minimal structural requirements for function (Bonsing and Mackinlay, 1987). Sequence alignments of CN genes from various species reveal evidence of a high mutation rate including insertions, deletions, and sequence rearrangements (Bawden and Nicholas, 1999). Nevertheless, comparative analysis of $\mathrm{CN}$ genomic sequences of human, rodent, and cattle shows that the organization and orientation of the genes is greatly conserved, and the molecular diversity of the $\mathrm{CN}$ genes is achieved through variable use of exons in different species and great evolutionary divergence (Rijnkels, 2002). Nutritionally, caseins provide the suckling neonate with a source of amino acids, highly bioavailable calcium, and potential bioactive peptides (i.e., antimicrobial, immune modulating).

Interspecies comparisons demonstrated that CSN3 possesses the greatest degree of conservation among the $\mathrm{CN}$ genes, which might be related to its essential function of $\mathrm{CN}$ micelle stabilizer (Alexander et al., 1988). Investigation at the DNA level allows the comparison between synonymous and nonsynonymous mutations. Gatesy et al. (1996) compared CSN3 exon IV of 21 mammalian taxa and reported similar rates for synonymous and nonsynonymous substitutions per site, with the divergence at each codon position being roughly equivalent. This pattern of divergence at CSN3 was interpreted by the authors as supporting a strictly neutral model of evolution for this gene. In contrast with a neutral evolution model, Ward et al. (1997) reported strong positive selection on the CMP between distantly related bovid taxa, leading to an accelerated divergence of this peptide within a 34-codon region. In closely related species, this pattern was not observed. Consequently, the authors predicted less polymorphism of CMP within species and more extensive polymorphism between species.

The availability of the Bos taurus genome sequence assembly marks the beginning of a new era for the study of milk and mammary biology. Using this assembly, Lemay et al. (2009) identified 197 unique milk protein genes and found the genes encoding milk components and other genes expressed in the mammary gland to be under more stringent selection constraints (negative selection) compared with the rest of the genome, aiming to maximize the survival of both mother and offspring. This highlights the importance of milk in mammalian evolution. Evidence of positive selection,
Table 5. Position within the gene and mature protein of the $L A A$ genetic variants in Bos genus ${ }^{1}$

\begin{tabular}{lccc}
\hline & \multicolumn{3}{c}{$L A A$ variants } \\
\cline { 2 - 4 } Gene, Protein & $B$ & $A$ & $C$ \\
\hline 851 & CGG & CAG \\
10 & Arg & His & \\
$?^{2}$ & $?$ & & $?$ \\
$?$ & Asp? & & Asn? \\
\hline
\end{tabular}

${ }^{1}$ The reference sequence is GenBank No. X06366, corresponding to $L A A^{*} B . L A A^{*} C$ was found only in Bos javanicus.

${ }^{2}$ ? = The $C$ variant was reported to differ from $B$ by having either an Asn-for-Asp or a Gln-for-Glu substitution (Bell et al., 1981).

even if not significantly different under the likelihood ratio test, was found for CSN2 and CSN3 (Lemay et al., 2009). The authors concluded that the requirement that the entire gene show statistical evidence of positive selection might be too stringent and further sitespecific evolutionary analysis of the casein genes might be warranted. Thus, the debate on the evolution model of $C S N 3$ still needs further investigations in light of the more recent molecular knowledge.

This type of research is indeed very attractive because the main interest in milk protein polymorphism studies is to understand the biological significance of the genetic variation, which can be highlighted by evolutionary studies.

\section{THE CN HAPLOTYPE AND SIRE SELECTION}

As already mentioned, knowledge of $\mathrm{CN}$ gene variation at the haplotype level has been a useful tool in biodiversity studies. As an example, the comparison of African Bos taurus and Bos indicus breeds allowed the identification of several Bos indicus-specific haplotypes $\left(C S N 1 S 1{ }^{*} C-C S N 2{ }^{*} A^{2}-C S N 3 * A^{I} / C S N 3 * H\right)$ that were not found in pure taurine breeds. The occurrence of such haplotypes in southern European breeds suggested that an introgression of indicine genes into taurine breeds could have contributed to the distribution of the genetic variation observed (Jann et al., 2004).

Casein haplotype effects on productive traits have also been investigated, considering information on the whole CN complex. The latter approach is recommended for both research and breeding purposes, possibly taking into account all CN variants, as well as other important polymorphisms in the noncoding regions. Instead of analyzing effects of single alleles, a series of studies has focused on the estimation of CN haplotype effects, as discussed in the following.

Lien et al. (1995) considered other sites of polymorphism within the CN area of chromosome 6 and found a significant favorable effect of a paternal haplotype on 
Table 6. Position within the gene and mature protein of the $L G B$ genetic variants in Bos genus ${ }^{1}$

\begin{tabular}{|c|c|c|c|c|c|c|c|c|c|c|c|}
\hline Gene, Protein & \multicolumn{11}{|c|}{$L G B$ variant } \\
\hline 3065 & GAG & & & $\mathrm{CAG}^{2}$ & & & & & & & \\
\hline 3080 & CCT & & & & & $\mathbf{T C T}^{2}$ & & & & & \\
\hline 50 & Pro & & & & & Ser & & & & & \\
\hline 3098 & ATC & & & & & & & & & & $\mathrm{CTC}^{2}$ \\
\hline 3982 & $\mathrm{AA} C$ & $\mathrm{AA} T$ & & & $?^{3}$ & $?$ & $?$ & $?$ & $?$ & $?$ & $?$ \\
\hline 63 & Asn & & & & & & & & & & \\
\hline 3984 & GGT & GAT & & & & & & GAT & & & \\
\hline 64 & Gly & Asp & & & & & & Asp & & & \\
\hline 4003 & $\mathrm{AAG}$ & & & & & & & AA? & & & \\
\hline 70 & Lys & & & & & & & Asn & & & \\
\hline 108 & Glu & & & & & & & & Gly & & \\
\hline 5263 & $\mathrm{GCC}$ & GTC & & & & & & $\mathrm{GTC}^{2}$ & & & \\
\hline 118 & Ala & Val & & & & & & Val & & & \\
\hline 5962 & $\mathrm{CCG}$ & & & & & & & & & $\mathrm{CTG}^{2}$ & \\
\hline 126 & Pro & & & & & & & & & Leu & \\
\hline 5970 & GAC & & & & & $\mathbf{T A C}^{2}$ & & & & & \\
\hline 129 & Asp & & & & & Tyr & & & & & \\
\hline 6280 & GAG & & & & $\mathrm{GGG}^{2}$ & $\mathrm{GGG}^{2}$ & $\mathrm{GGG}^{2}$ & & & & \\
\hline 158 & Glu & & & & Gly & Gly & Gly & & & & \\
\hline
\end{tabular}

${ }^{1}$ The reference variant is $L G B^{*} B$ (GenBank No. X14710). Nonsynonymous and synonymous mutations are respectively bolded and in italics within each codon. $L G B^{*} E$ was found in Bos grunniens and Bos javanicus, $L G B^{*} F$ and $L G B^{*} G$ only in Bos javanicus.

${ }^{2}$ The most probable codon is reported, considering that only one SNP occurred within the triplet.

${ }^{3} ?=$ Information not available.

milk protein yield in a Norwegian cattle family. This haplotype was named $C$ - $A 5-16-A$ because it carries, in addition to $C S N 1 S 1^{*} C$, the $C S N 2^{*} A^{5}$ allele, which shows a silent $\mathrm{C}>\mathrm{T}$ mutation in codon 110 , the mature protein not being different from $\operatorname{CSN}^{*} A^{2}$ (Lien and Rogne, 1993). This haplotype also carries a microsatellite in $C S N 3$ intron 3 with 16 repeats instead of 14 , as well as allele $C S N 3^{*} A$.

The analysis of the effects of paternal haplotypes within sires revealed the opposite effect of haplotypes for 2 of the 7 sires for casein content (Braunschweig et al., 2000). This inconsistency gave rise to speculation that the $\kappa$-CN allele might be connected to different promoters or cis-acting regulatory sequences. Various significant effects have been observed by Boettcher et al. (2004), particularly for protein content in milk, in Italian Holstein and Brown breeds, in agreement with previous scans of chromosome 6 (Kühn et al., 1999; Velmala et al., 1999). Among the haplotypes, $B-A^{1}-B$ (in the order: CSN1S1-CSN2-CSN3) was associated with increased percentage of both fat and protein in Finnish Ayrshire (Ikonen et al., 2001) and Italian Hol- stein and Brown cattle but had negative effects on milk yield (Boettcher et al., 2004). The $C-A^{2}-B$ haplotype was associated with significantly decreased yield and increased concentration of protein, whereas, in general, haplotypes carrying the $C S N 3^{*} B$ allele had positive effects on protein percentage relative to the corresponding haplotypes carrying $\operatorname{CSN}^{*}{ }^{*} A$ (Boettcher et al., 2004). In a recent investigation of the Dutch Holstein-Friesian population, Heck et al. (2009) concluded that selection for CSN2-CSN3 haplotype $A^{2}-B$, together with $L G B^{*} B$, would result in cows that produce milk more suitable for cheesemaking.

The main problems in comparing research studies considering haplotypes are i) the different points of mutations used for constructing the casein haplotype and ii) difficulties in reconstructing the exact haplotypes carried by each animal. Besides the genotype of the animals at the single polymorphism of interest, both pedigree information and parent typing at the same polymorphisms should be available for an accurate diagnosis, mainly if several mutations are considered within the $\mathrm{CN}$ region. In all cases, correlations among 
Table 7. Distribution and discovery year of the milk protein variants reported in Tables $1-6^{1}$

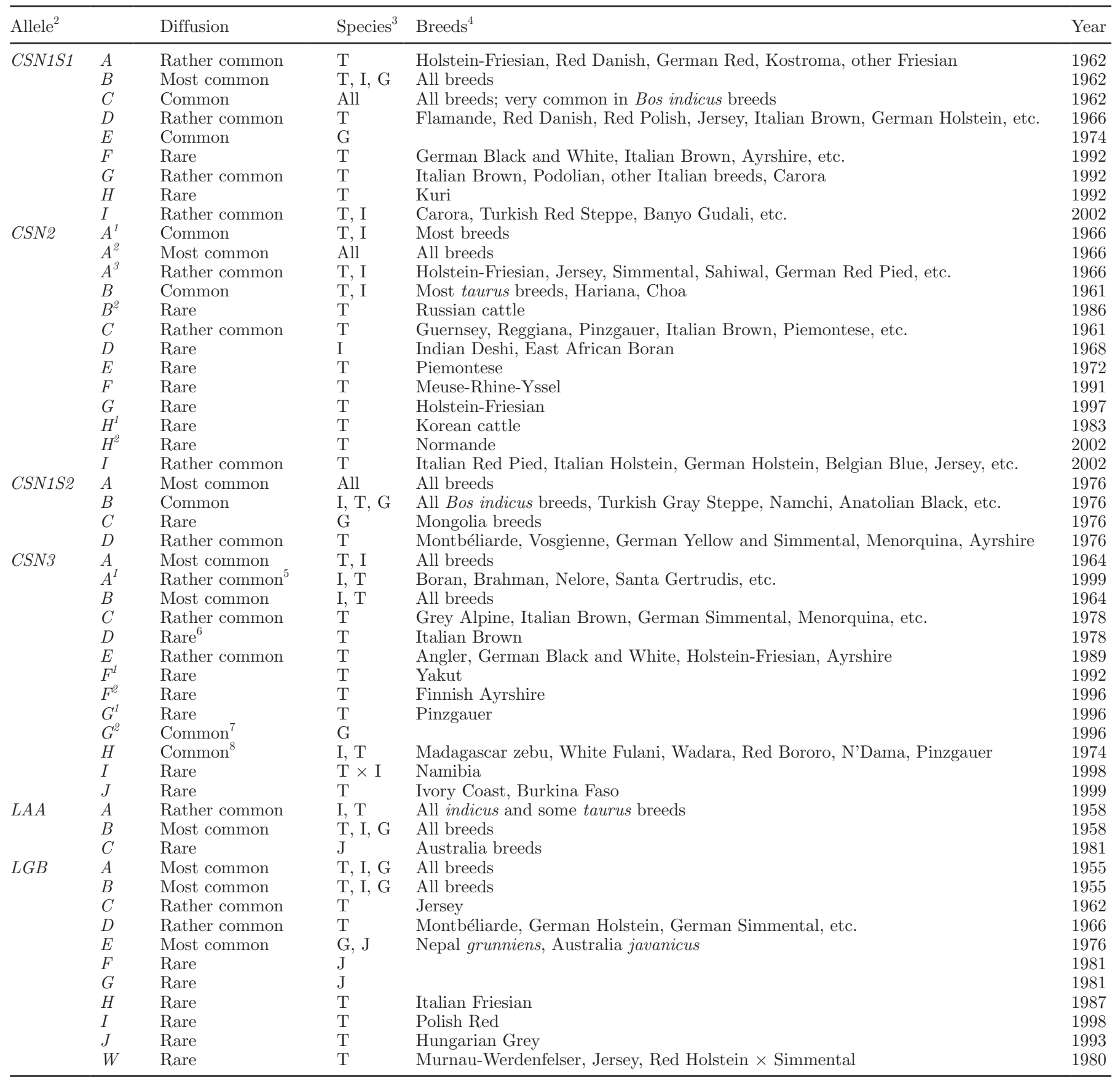

${ }^{1}$ Information is taken from the survey by Formaggioni et al. (1999) and from Boettcher et al. (2004), Jann et al. (2004), Ibeagha-Awemu et al. (2007), and Caroli et al. (2008).

${ }^{2}$ Superscripts indicate different variants.

${ }^{3} \mathrm{~T}=$ Bos taurus $; \mathrm{I}=$ Bos indicus $; \mathrm{G}=$ Bos grunniens; $\mathrm{J}=$ Bos javanicus.

${ }^{4}$ When a list of breeds is reported, the first breed is the one in which the allele was first identified.

${ }^{5}$ Rather high frequencies in some Bos indicus breeds; also found in Boran $\times$ N'Dama, Friesian $\times$ Sahiwal crosses.

${ }^{6}$ Depending on the exact molecular characterization of the allele, it could be more common (see text).

${ }^{7}$ Other variants were recently identified in Bos grunniens (see text), and more details about their distribution are needed.

${ }^{8}$ Mainly in Bos indicus. 
breeds tended to be high and positive, indicating that haplotypes had similar effects in the different breeds and suggesting that the $\mathrm{CN}$ genes themselves were responsible for the haplotype effects observed, rather than genes physically linked to the $\mathrm{CN}$ complex (Boettcher et al., 2004).

Nilsen et al. (2009) recently constructed a high-resolution SNP map of the bovine CN region to study associations with milk traits in Norwegian Red cattle and suggested separation of the CN cluster into 2 haplotype blocks, one consisting of CSN1S1, CSN2, and CSN1S2, and the other of CSN3. Highly significant associations with both protein and milk yield were found within the CSN1S1-CSN2-CSN1S2 haplotype block. In contrast, no significant association was found within the CSN3 block. The authors pointed toward CSN2 and CSN1S2 as the most likely genes harboring the underlying causative DNA variation. The most significant results involved the CSN2_67 SNP, a C > A nt substitution in codon 67 that results in the AA exchange Pro to His, with $\mathrm{C}$ being consistently associated with greater protein and milk yield. Of the 12 CSN2 variants (Table 2), A nt occurs in $C S{ }^{2} 2^{*} A^{1}, C S N 2^{*} B, C S N 2^{*} C$, and the less common $C S N 2^{*} F$ and $C S N 2^{*} G$ within a triplet coding for $\mathrm{His}_{67}$ in the mature protein, whereas $\mathrm{C}$ nt occurs in $\operatorname{CSN}^{*} A^{2}, C S N 2^{*} A^{3}$, and in the other CSN2 variants, resulting in $\mathrm{PrO}_{67}$.

This short overview of the CN cluster confirms the importance of taking the whole haplotype into account for breeding strategies. The effects of alleles or SNP within the $\mathrm{CN}$ cluster determined by different authors in different breeds are sometimes conflicting (Nilsen et al., 2009), similar to QTL scans of chromosome 6 (Olsen et al., 2005). An explanation of such inconsistent findings might be that the haplotype balances, in some still unknown way, the constraints imposed by natural and/or artificial selection at the DNA region harboring the $4 \mathrm{CN}$ genes, which are essential for both newborn cattle survival and breeding purposes. Recently, several QTL affecting milk protein composition (casein, whey protein, and specific protein content) were found, with the most significant regions being on Bos taurus autosomes 6, 11, and 14 (Schopen et al., 2009). The future use of genomic selection in animal breeding will have to take into account not only single SNP information but also particular "hot" zones of the animal genome, such as the CN cluster, where interactions among coding and noncoding nt can strongly influence the overall gene expression.

\section{NONCODING POLYMORPHISMS}

The so-called noncoding DNA variants are located in the noncoding regions of genes $\left(5{ }^{\prime}\right.$-untranslated region including promoters, 3 '-untranslated region, and introns or intragenic regions), as well as intergenic regions, and some of them have significant associations with production traits (Ibeagha-Awemu et al., 2008).

The noncoding sequences of milk protein genes have been intensively investigated. Important mutations altering the specific protein expression, and therefore milk composition, were found. Intronic mutations might affect splice sites and, consequently, mRNA stability and lead to truncated protein products or even lack of them. In bovine $C S N 1 S 1^{*} A$, an SNP at position +6 in the splice donor sequence of exon 4 results in upstream exon skipping during pre-mRNA processing, with reduced $\alpha_{\mathrm{s} 1}-\mathrm{CN}$ expression (Mohr et al., 1994).

The bovine $C S N 1 S 1{ }^{*} G$ allele, associated with lower proportion of $\alpha_{\mathrm{s} 1}-\mathrm{CN}$ in milk, is characterized by a 371 insertion in noncoding exon 19 (Rando et al., 1998). The smaller amount of $\alpha_{\mathrm{s} 1}$-CN associated with $C S N 1 S 1{ }^{*} G$ can be explained by a reduced mRNA stability resulting from the insertion, which has a high homology with relics of long interspersed elements of retropositional origin. An SNP within a short interspersed nt element Bov-A2 was described by Damiani et al. (2000b) in the second intron of $\mathrm{CSN}_{3}$ and found to be in linkage disequilibrium with the $\mathrm{\kappa}-\mathrm{CN}$ protein variants (Damiani et al., 2000a) and also associated with several milk production traits (Damiani et al., 2001).

Polymorphisms of the CSN1S1 promoter have revealed significant associations with milk protein content (Prinzenberg et al., 2003). Thus, the CN cluster polymorphism has to be considered as a whole complex in which expression sequence polymorphisms could help explain the productive implications of the different CN loci and their corresponding haplotypes.

Examples of noncoding variants are also known to affect whey proteins. In numerous studies, starting from Cerbulis and Farrell (1975), a greater protein expression level of the $\beta$-LG A variant compared with the B variant has been reported. Two SNP lead to AA changes and are the causal genetic polymorphisms of the protein variants $\beta$-LG $\mathrm{A}$ and $\beta$-LG $\mathrm{B}$ respectively coded by $L G B^{*} A$ and $L G B^{*} B$. The functional reason for differences in expression between the 2 alleles has been investigated by several authors. Wagner et al. (1994) described 14 SNP in the 5'-flanking region and 2 SNP in the $5^{\prime}$-untranslated region of $L G B$. Lum et al. (1997) found 10 polymorphic sites distinguishing $L G B^{*} A$ and $L G B^{*} B$ promoters, one of which, a $\mathrm{G}>\mathrm{C}$ transversion at position -430 , is located within a consensus binding site for activator protein-2. The differential affinity of activator protein-2 to $L G B^{*} A$ and $L G B^{*} B$ promoters has been demonstrated in vitro, being $60 \%$ greater for the activator protein- 2 recognition site of $L G B^{*} A$ (Lum et al., 1997). Folch et al. (1999) confirmed the 


\section{CSN1S1}

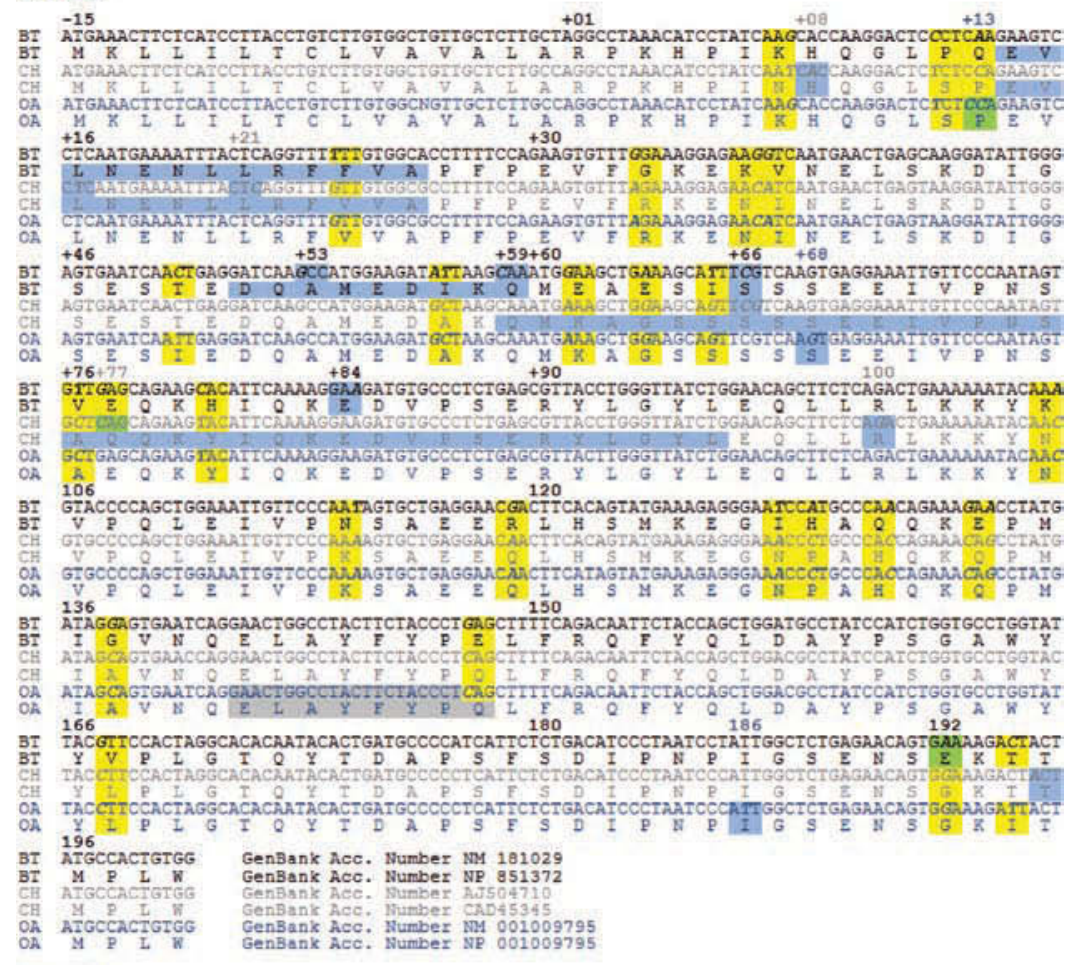

\section{CSN1S2}

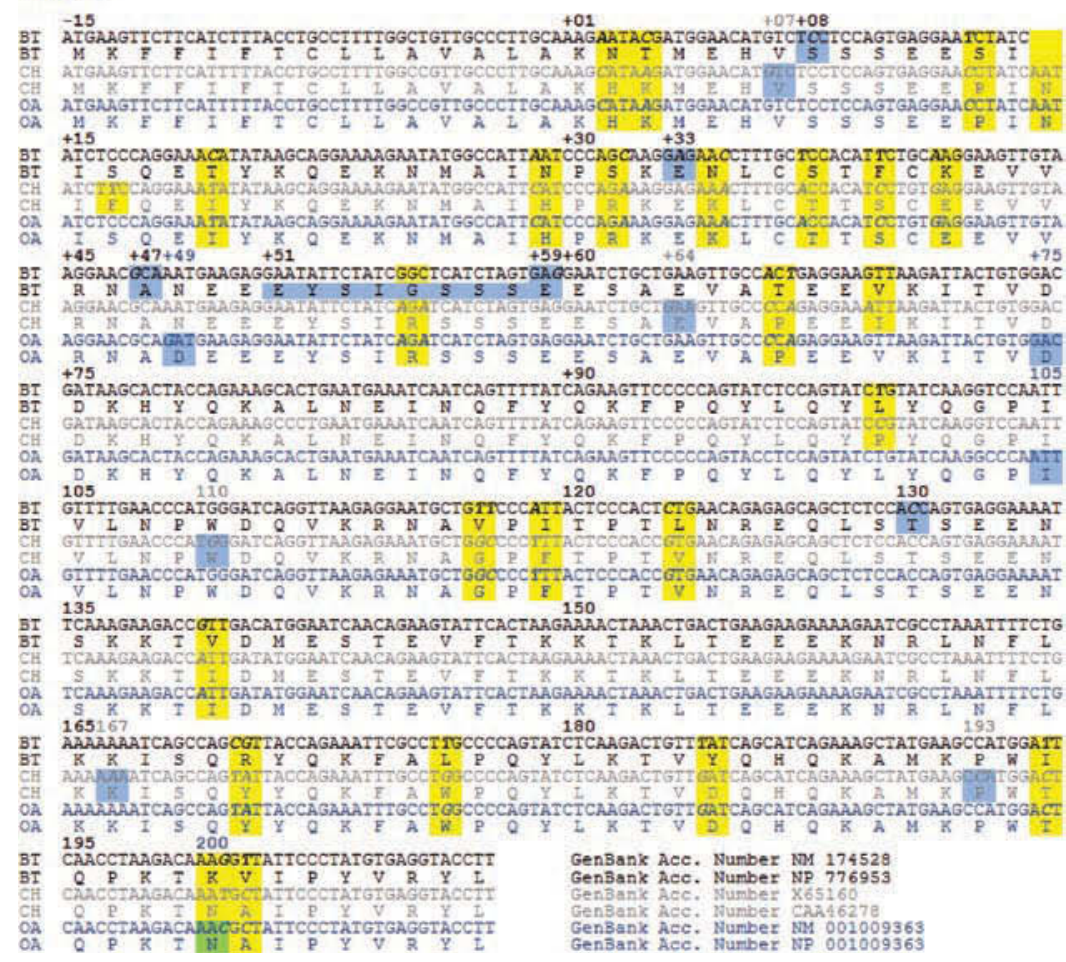

Figure 2a. Alignment of the sequences of Bos taurus (BT), Capra hircus (CH), and Ovis aries (OA) casein genes (lines 1, 3, and 5) and preprotein (lines 2, 4, and 6). The positions above the first line refer to the protein, starting from the signal peptide (indicated as negative values) to the first AA of the mature protein $(+01)$. Highlighted in yellow: nucleotides and AA differing in Capra hircus and/or Ovis aries with respect to Bos taurus; in blue: nucleotide and/or AA in which intraspecies genetic variations occur; in green: both interspecific and intraspecific variation occur; in gray: missing or conflicting data (AA 141-148 are not available in the ovine reference sequence; AA -9 is not clearly defined from the ovine nucleotide sequence; AA 137 is a controversial inversion with AA 138 in the bovine CSN2 sequence, see Table 2). Nucleotides affected by interspecific or intraspecific variation are bolded and in italics. CSN1S1 $=\alpha_{\mathrm{s} 1}$ CN gene; CSN1S2 $=\alpha_{\mathrm{s} 2}$-CN gene. 


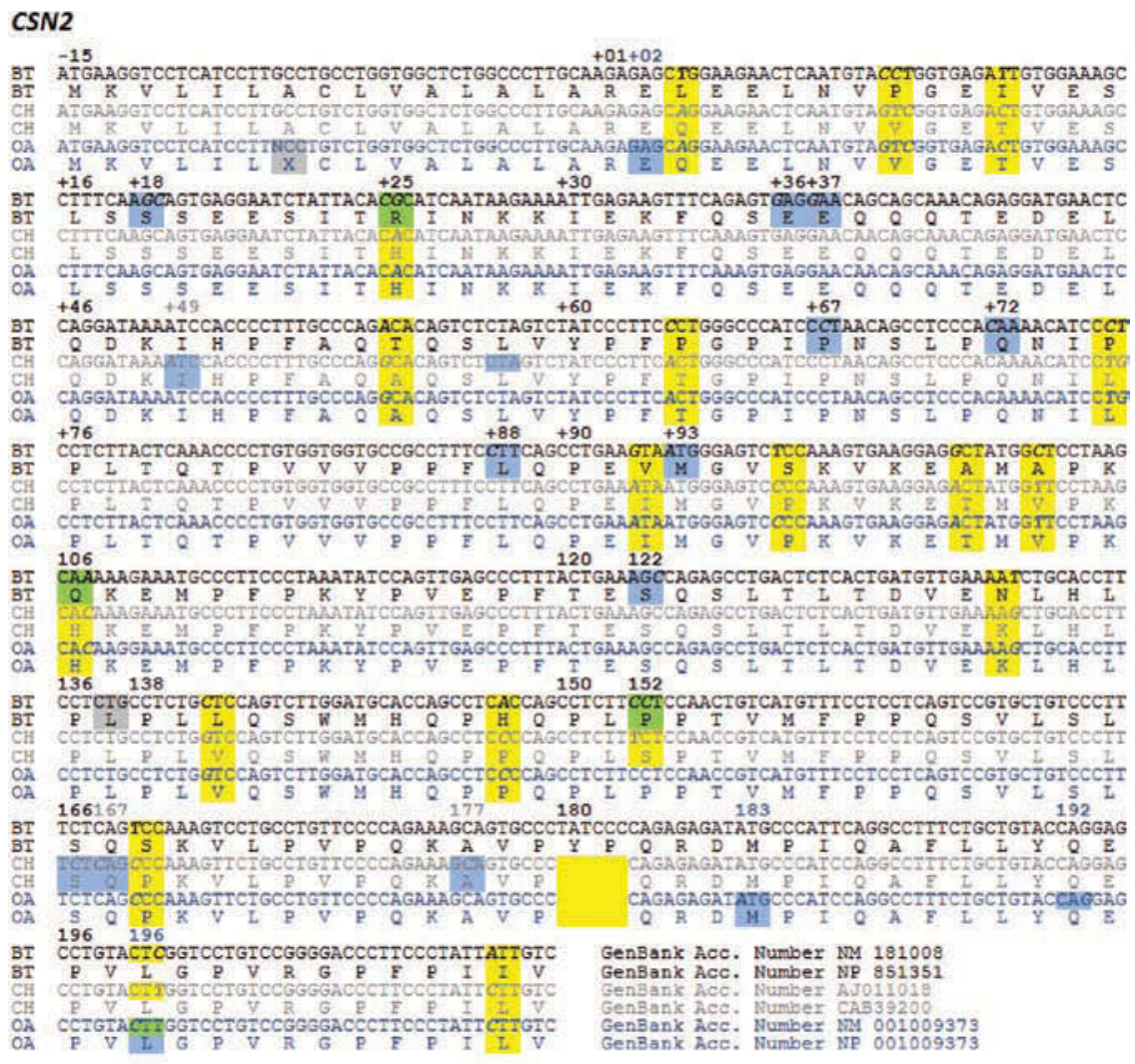

CSN3

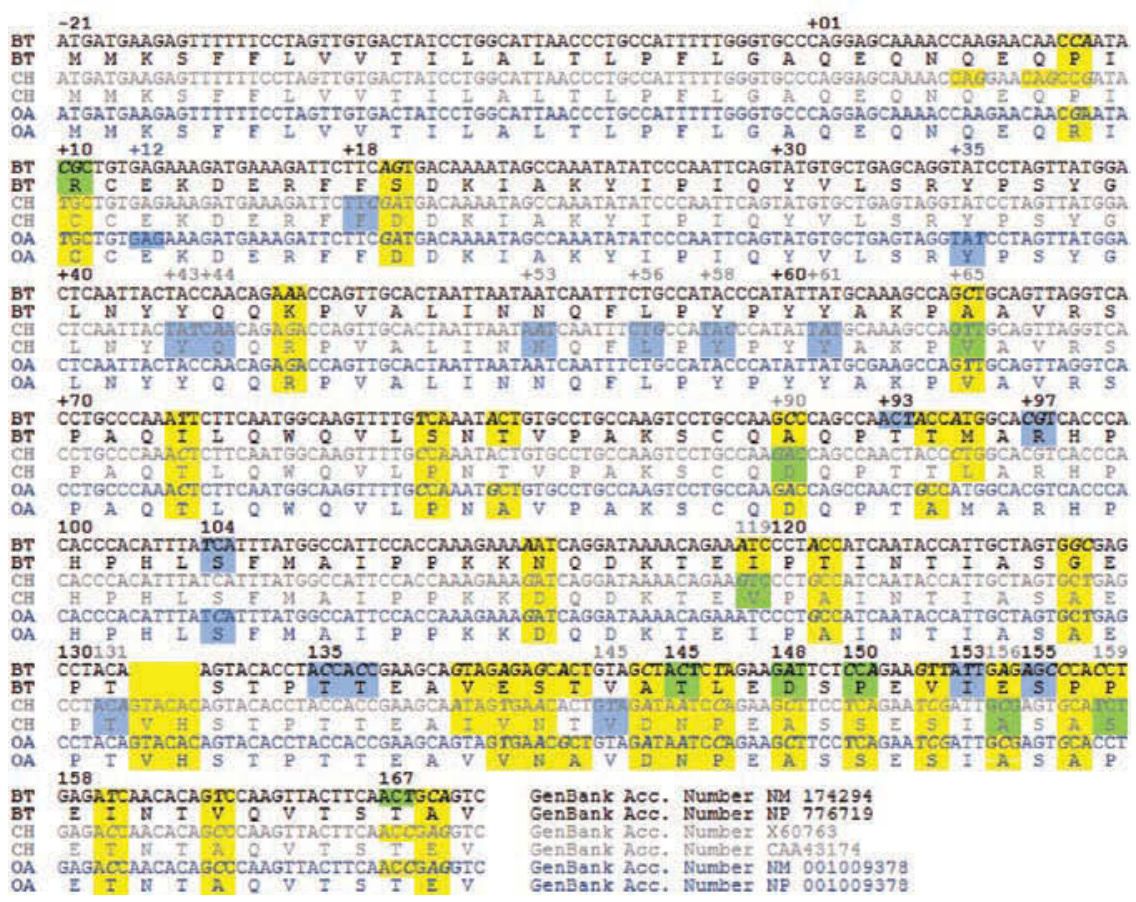

Figure 2b. Alignment of the sequences of Bos taurus (BT), Capra hircus (CH), and Ovis aries (OA) casein genes (lines 1, 3, and 5) and preprotein (lines 2, 4, and 6). The positions above the first line refer to the protein, starting from the signal peptide (indicated as negative values) to the first AA of the mature protein (+01). Highlighted in yellow: nucleotides and AA differing in Capra hircus and/or Ovis aries with respect to Bos taurus; in blue: nucleotide and/or AA in which intraspecies genetic variations occur; in green: both interspecific and intraspecific variation occur; in gray: missing or conflicting data (AA 141-148 are not available in the ovine reference sequence; AA -9 is not clearly defined from the ovine nucleotide sequence; AA 137 is a controversial inversion with AA 138 in the bovine CSN2 sequence, see Table 2). Nucleotides affected by interspecific or intraspecific variation are bolded and in italics. CSN2 $=\beta-\mathrm{CN}$ gene; CSN3 $=\kappa-\mathrm{CN}$ gene. 
differential transcription activity controlled by $\beta$-LG A and B-specific promoters, with a 57 and $43 \%$ level of expression for $L G B^{*} A$ and $L G B^{*} B$ promoters, respectively.

More recently, Ganai et al. (2008) detected 50 polymorphisms in the coding, intron, and promoter regions of bovine $L G B$ gene, of which 33 had not been described before. The authors concentrated their attention on 8 polymorphisms not in complete linkage disequilibrium with $\beta$-LG A and B. One of them (g.-731G > A) had a significant effect on $\beta$-LG, the A nt reducing the relative $\beta$-LG concentration in animals homozygous for the $L G B^{*} A$ variant.

In addition, an extremely weak $\beta$-LG $B$ variant band has been observed in Brown Swiss cattle, and the putative responsible allele was named $\beta$-LG B* (Kim et al., 1996). The C $>$ A SNP at position 215 bp upstream of the translation initiation site (g.-215C > A) was found to be associated with an abnormally reduced expression of $\beta$-LG characterizing this variant (Braunschweig and Leeb, 2006).

As far as $L A A$ is concerned, Bleck and Bremel (1993a) identified 3 SNP in Holstein-Friesian within the 5 -flanking region at positions $+15,+21$, and +54 from the mRNA transcription starting point. The +15 and +21 SNP were in the $5^{\prime}$-untranslated region, whereas the +54 SNP was a silent mutation in the coding region. An A $>$ G SNP differentiated $L A A(+15)^{*} A$ from $L A A(+15)^{*} B$. The former allele was associated with greater milk, protein, and fat yields, and the latter was associated with greater protein and fat percentage (Bleck and Bremel, 1993b). This SNP was also detected in Taiwan Holstein, Italian Friesian, Italian Red Pied, Swedish Red and White, and Italian Brown (Formaggioni et al., 1999). Voelker et al. (1997) found another SNP located in position -1689 from the transcription start point of $L A A$ in complete linkage disequilibrium with $L A A(+15)$.

\section{MILK PROTEIN VARIANTS AND HUMAN NUTRITION}

It is noteworthy that milk protein polymorphisms are involved in human nutrition in various ways. Three crucial aspects include i) the hypoallergenic properties of particular types of milk, ii) the release of peptides with biological functions from milk proteins, and iii) the coevolution of bovine milk protein variants and human lactose tolerance.

\section{Hypoallergenic Milk}

Most milk proteins are potential allergens, mainly $\alpha_{\mathrm{s} 1}-\mathrm{CN}, \alpha_{\mathrm{s} 2}-\mathrm{CN}$, and $\beta-\mathrm{LG}$, which are missing in human milk (EFSA, 2004; Crittenden and Bennett, 2005).
The occurrence of alleles associated with null or faint content of those proteins might be exploited for the production of milk with particular nutritional qualities; that is, hypoallergenic properties. In this regard, the bovine $C S N 1 S 1^{*} G$ (Rando et al., 1998) might be exploited for the production of milk with reduced expression of the specific protein. This is also true for the numerous goat $\mathrm{CN}$ alleles associated with null or reduced CN expression (Rando et al., 2000), which deserve a brief description. Of the 45 goat $\mathrm{CN}$ alleles that have been identified (summarized in Caroli et al., 2006; Chessa et al., 2008b), 8 and 4 alleles have been associated with null and reduced content, respectively, of the specific calcium-sensitive $\alpha_{\mathrm{s} 1}-\mathrm{CN}, \alpha_{\mathrm{s} 2}-\mathrm{CN}$, and $\beta$-CN. Moreover, a significant variation has been found in milk $\mathrm{CN}$ content between the 2 groups of goat CSN3 variants characterized by different isoelectric points (Chiatti et al., 2007).

Comparison among cattle, goat, and sheep CN coding sequences (Figures $2 \mathrm{a}$ and $2 \mathrm{~b}$ ) highlights the lower within-species polymorphism characterized in the ovine species (Amigo et al., 2000; Chessa et al., 2003), with a total of only 14 mutations identified in Ovis aries versus 31 (plus 3 deletions) in Bos taurus and 31 (plus 2 deletions) in Capra hircus. Two deletions affect the same AA in Bos taurus and Capra hircus, involving AA $14-26$ of $\alpha_{\mathrm{s} 1}-\mathrm{CN}$ in bovine $C S N 1 S 1^{*} A$ and goat $C S N 1 S 1^{*} G$ variant, respectively (Rando et al., 2000). The associated interspecific and intraspecific variations are highlighted in green in Figures 2a and 2b. They occur only at the calcium-sensitive $\mathrm{CN}$ in Ovis aries, whereas they also affect CSN3 in Bos taurus and Capra hircus. Most variations affect the first half of the mature protein in CSN1S1 and CSN1S2, are more uniformly distributed in CSN2, and are clearly located in the second half of the CSN3 gene, coding for CMP with an important possible influence on the biological actions of this peptide.

Besides selecting for milk with null or reduced content of a specific protein, another possibility for producing hypoallergenic milk could involve genetic differences among epitopes, which are short fragments widely spread throughout hydrophobic parts of the protein molecules. Epitopes on milk proteins comprise highly conserved sequences responsible for IgE cross-reactivity with corresponding milk proteins of other mammals, including humans (Wal, 2004). The genetic variation might affect the IgE-binding epitope structure of milk proteins, and as a consequence, milk produced by different genotypes could give different allergenic reactions. Lisson and Erhardt (2008) demonstrated with an in silico study that different epitopes occurring at bovine milk proteins are modified within the genetic variants, as has also been found in the caprine species (Chessa et 
al., 2008a). Focusing on the most allergenic fractions, $\alpha_{\mathrm{s} 1}-\mathrm{CN}$ and $\beta-\mathrm{LG}$, interesting differences resulting from genetic variations were observed for $C S N 1 S 1^{*} A$ and $C S N 1 S 1{ }^{*} C$ compared with $C S N 1 S 1^{*} B$, whereas 7 AA exchanges were found within 5 epitopes of $\beta$-LG in 6 rare $L G B$ variants, compared with $L G B^{*} B$ (Lisson and Erhardt, 2008).

\section{Biopeptides}

In recent years it has been recognized that dietary proteins provide a rich source of biologically active peptides. Biopeptides have been defined as specific protein fragments that have a positive effect on body functions or conditions and might ultimately influence health (Kitts and Weiler, 2003). Such peptides are inactive within the sequence of the parent protein and can be released by enzymatic proteolysis during gastrointestinal digestion or food processing (Fitzgerald and Murray, 2006; Korhonen and Pihlanto, 2006). Caseins represent a reservoir for a wide variety of bioactive peptides, minor regulatory compounds with hormone-like activity, which could affect milk nutritional value (Meisel, 1998; Lorenzini et al., 2007).

The biological activity of peptides released from milk protein digestion might be affected by AA exchanges or deletions resulting from gene mutations. As an example, variant $C S N 2^{*} A^{2}$ and $C S N 2 * A^{3}$ differ from $C S N 2^{*} A^{1}$, $C S{ }^{2}{ }^{*} B$, and $C S{ }^{2}{ }^{*} C$ for the presence of a proline instead of a histidine at position 67 of the mature protein. Histidine ${ }_{67}$ determines the enzymatic cleavage of the peptide bond releasing $\beta$-casomorphin- 7 , which has opioid properties resulting in an immune suppressant influence most probably implicated in the etiology of type 1 diabetes. It has been suggested that consumption of milk from $\mathrm{His}_{67}$-carrying cows is positively and significantly correlated with diabetes incidence because of the release of $\beta$-casomorphin-7 (Elliott et al., 1999). Another trial on $\beta$-casomorphin- 8 on the inhibition of muscle contraction in guinea pigs suggested a difference, even if not statistically significant, between $\beta$-casomorphin-8-His and $\beta$-casomorphin-8-Pro, the first peptide showing a greater inhibition on muscle contraction (Hartwig et al., 1997). It has also been suggested that a high consumption of $\mathrm{His}_{67}$ milk increases the risk of ischemic heart disease (McLachlan, 2001), sudden infant death syndrome (Sun et al., 2003), and the aggravation of symptoms associated with schizophrenia and autism (reviewed in Knivsber et al., 2001) and might correlate with milk allergy (Chatchatee et al., 2001a, b) in humans.

Because high consumption of milk carrying $\mathrm{His}_{67}$ (namely $C S N 2^{*} A^{1}, C S N 2^{*} B$, and $C S N 2^{*} C$ ) has been alleged to affect human health by increasing the risk of diabetes and heart disease, an increase in the frequency of alleles or haplotypes coding for $\mathrm{PrO}_{67}$ at $\beta-\mathrm{CN}$ by selective breeding has been suggested by Nilsen et al. (2009). However, Hernández-Ledesma et al. (2004) demonstrated the formation of an angiotensin-I-converting enzyme-inhibitory peptide specific to the bovine $C S N 2^{*} A^{1}$ variant that is not present in other $\beta-\mathrm{CN}$ alleles. Finally, caution is needed because of conflicting results on the potential health effect of $\beta$-casomorphins and related peptides recently reviewed in an European Food Safety Authority report (EFSA, 2009). In particular, a cause-effect relationship between the oral intake of $\beta$-casomorphin- 7 or related peptides and etiology of any suggested diseases cannot be established, and consequently, a formal European Food Safety Authority risk assessment of food-derived peptides is not recommended. This does not exclude, in our opinion, that milk produced from cows carrying particular genotypes might be suggested to be more suitable for human nutrition in specific pathology situations.

Despite the many studies and intensive debate on the so-called CSN2 $A^{2}$ milk (with $\mathrm{Pro}_{67}$ instead of $\mathrm{His}_{67}$, including CSN2 $A^{3}$ ), investigations on other genetic polymorphisms potentially affecting milk protein peptides are scarce. Two recent studies on biopeptides that took into account the effect of genetic polymorphisms are described in the following.

Weimann et al. (2009) investigated peptides derived from the genetic variants $A, B, C, E, F^{1}, F^{2}, G^{1}, G^{2}$, $H, I$, and $J$ of bovine CSN3 for their antihypertensive activities. Amino acid sequences of the CSN3 variants were analyzed in silico to detect potential inhibitory peptides against angiotensin-I-converting enzyme. Some CSN3 variants carried the following exclusive peptides whose angiotensin-I-converting enzyme-inhibitory activity was determined: ASP (within $C S N 3^{*} B$ ), AHHP $\left(\operatorname{CSN}_{3}{ }^{*} C\right)$, VSP $\left(C S N 3^{*} F^{1}\right)$, and ACHP $\left(C S N 3^{*} G^{2}\right)$.

Among biopeptides, phosphopeptides are strongly phosphorylated peptides known to exert an effect on calcium metabolism but also on other minerals (Bouhallab and Bouglé, 2004). Consumption of high concentrations of calcium in early life contributes to the development of maximal bone density, which, in turn, can prevent osteoporosis in later life. The high bioavailability of calcium from milk and dairy products has, in part, been attributed to the production of caseinophosphopeptides with different levels of phosphorylation (Fitzgerald, 1998). Caroli et al. (2009) investigated the effects of 4 selected casein peptides on osteoblast mineralization in vitro. The chosen peptides were related to different casein genetic variants, in particular $C S N{ }^{*} C$ and $C S N 1 S 2{ }^{*} C$ versus the other CSN2 and CSN1S2 variants, respectively. The authors suggested that the distinct peptides might differentially affect calcium de- 
position in the extracellular matrix and that the genetic variation is involved in their differential effect.

\section{Coevolution of Bovine Milk Genetic Variants and Human Lactose Tolerance}

A gene-culture coevolution between cattle milk protein genes and human lactase genes has been recently highlighted (Beja-Pereira et al., 2003). Milk from domestic cows has been a valuable food source for over $8,000 \mathrm{yr}$, especially in lactose-tolerant human societies that have exploited dairy breeds. Some human populations (e.g., northern Europe) have the genetically determined ability to digest lactose by the action of persistent lactase enzyme in adulthood, thereby benefiting from the rich food resources in cows' milk. The geographic patterns of the variation in genes encoding the 6 most important milk proteins were studied in 70 native European cattle breeds (Beja-Pereira et al., 2003). The authors found a substantial geographic correspondence between high diversity in cattle milk genes, location of the European Neolithic cattle farming sites ( $>5,000$ yr ago), and present-day lactose tolerance in Europeans. The authors proposed that since the Neolithic times, there has been a gene-culture coevolution between the domestic cattle and human culture driven by the advantage conferred by milk consumption. This led to the maintenance of larger herds and selection for increased milk yield and altered milk protein composition. The gene-culture coevolution between cattle milk protein genes and human lactase genes described is an impressive proof of the nonrandom occurrence of milk protein genetic variation over the ages.

\section{CONCLUSIONS}

The genomic and proteomic approach is a useful tool for gaining a better understanding of both how selection has modified the ruminants' germplasm at the level of milk protein structural genes and how animal breeding could better exploit the genetic reservoirs of the different genes and breeds. The great variation highlighted in the genes, proteins, and peptides that are so important for dairy production is a crucial element in providing milk with different properties at the level of the protein system. This is important for possible technological use and for the nutraceutical value of dairy products. Designing milk with different protein structures appropriate for its specific use is becoming more and more feasible for breeders and is an important task for animal geneticists.

\section{ACKNOWLEDGMENTS}

The authors thank Daniela Rignanese (Dipartimento di Scienze Biomediche e Biotecnologie, Università degli
Studi di Brescia, Brescia, Italy) and Maria Lisson (Institut für Tierzucht und Haustiergenetik, Justus-LiebigUniversität, Gießen, Germany) for their kind support. Thanks to all the animal breeders throughout the world who have supported us.

\section{REFERENCES}

Aleandri, R., L. G. Buttazzoni, J. C. Schneider, A. Caroli, and R. Davoli. 1990. The effects of milk protein polymorphisms on milk components and cheese-producing ability. J. Dairy Sci. 73:241255.

Alexander, L. J., A. F. Stewart, A. G. Mackinlay, T. V. Kapelinskaya, T. M. Tkach, and S. I. Gorodetsky. 1988. Isolation and characterization of the bovine kappa-casein gene. Eur. J. Biochem. 178:395-401.

Amigo, L., I. Recio, and M. Ramos. 2000. Genetic polymorphism of ovine milk proteins: Its influence on technological properties of milk-A review. Int. Dairy J. 10:135-149.

Aschaffenburg, R., and J. Drewry. 1957. Genetics of the $\beta$-lactoglobulins of cows' milk. Nature 180:376-378.

Bai, W. L., R. H. Yin, S. J. Zhao, Y. C. Zheng, J. C. Zhong, and Z. H. Zhao. 2008. Short communication: Characterization of a $\kappa$-casein genetic variant in the Chinese yak, Bos grunniens. J. Dairy Sci. 91:1204-1208.

Barroso, A., S. Dunner, and J. Canon. 1999. A multiplex PCR-SSCP test to genotype bovine beta-casein alleles $\mathrm{A}^{1}, \mathrm{~A}^{2}, \mathrm{~A}^{3}, \mathrm{~B}$, and $\mathrm{C}$. Anim. Genet. 30:322-323.

Bawden, W. S., and K. R. Nicholas. 1999. Molecular genetics of milk production. Pages 539-576 in The Genetics of Cattle. R. Fries and A. Ruvinsky, ed. CABI Publishing, New York, NY.

Beja-Pereira, A., G. Erhardt, C. Matos, L. Gama, and N. Ferrand. 2002. Evidence of a geographical cline of casein haplotypes in Portuguese cattle breeds. Anim. Genet. 33:295-300.

Beja-Pereira, A., G. Luikart, P. R. England, D. G. Bradley, O. C. Jann, G. Bertorelle, A. T. Chamberlain, T. P. Nunes, S. Metodiev, N. Ferrand, and G. Erhardt. 2003. Gene-culture coevolution between cattle milk protein genes and human lactase genes. Nat. Genet. 35:311-313.

Bell, K., K. E. Hopper, and H. A. McKenzie. 1981. Bovine $\alpha$-lactalbumin $\mathrm{C}$ and $\alpha$ s1-, $\beta$-, and $\kappa$-caseins of Bali (Banteng) cattle, Bos (Bibos) javanicus. Aust. J. Biol. Sci. 34:149-159.

Bleck, G. T., and R. D. Bremel. 1993a. Sequence and single-base polymorphisms of the bovine $\alpha$-lactalbumin 5 'flanking region. Gene 126:213-218.

Bleck, G. T., and R. D. Bremel. 1993b. Correlation of the $\alpha$-lactalbumin $(+15)$ polymorphism to milk production and milk composition of Holsteins. J. Dairy Sci. 76:2292-2298.

Boettcher, P. J., A. Caroli, A. Stella, S. Chessa, E. Budelli, F. Canavesi, S. Ghiroldi, and G. Pagnacco. 2004. Effects of casein haplotypes on production traits in Italian Holstein and Brown cattle. J. Dairy Sci. 87:4311-4317.

Bonsing, J., and A. G. Mackinlay. 1987. Recent studies on nucleotide sequences encoding the caseins. J. Dairy Res. 54:447-461.

Bouhallab, S., and D. Bouglé. 2004. Biopeptides of milk: Caseinophosphopeptides and mineral bioavailability. Reprod. Nutr. Dev. 44:493-498.

Braunschweig, M., C. Hagger, G. Stranzinger, and Z. Puhan. 2000. Associations between casein haplotypes and milk production traits of Swiss Brown cattle. J. Dairy Sci. 83:1387-1395.

Braunschweig, M. H., and T. Leeb. 2006. Aberrant low expression level of bovine $\beta$-lactoglobulin is associated with a $\mathrm{C}$ to $\mathrm{A}$ transversion in the BLG promoter region. J. Dairy Sci. 89:4414-4419.

Caroli, A., P. Bolla, E. Budelli, G. Barbieri, and P. Leone. 2000. Effect of k-casein E allele on clotting aptitude of Italian Friesian milk. Zoot. Nutr. Anim. 3:127-130.

Caroli, A., O. Bulgari, S. Chessa, D. Cocchi, and G. Tulipano. 2009. In vitro evaluation of caseinophosphopeptides from different genetic variants on bone mineralization. Ital. J. Anim. Sci. 8(Suppl. 2): $42-44$. 
Caroli, A., S. Chessa, F. Chiatti, D. Rignanese, B. Meléndez, R. Rizzi, and G. Ceriotti. 2008. Short communication: Carora cattle show high variability in $\alpha_{\mathrm{s} 1}$-casein. J. Dairy Sci. 91:354-359.

Caroli, A., F. Chiatti, S. Chessa, D. Rignanese, P. Bolla, and G. Pagnacco. 2006. Focusing on the goat casein gene complex. J. Dairy Sci. 89:3178-3187.

Cerbulis, J., and H. M. Farrell Jr.. 1975. Composition of milks of dairy cattle. I. Protein, lactose, and fat contents and distribution of protein fraction. J. Dairy Sci. 58:817-827.

Ceriotti, G., S. Chessa, G. Bramante, P. Bolla, E. Pieragostini, and A. Caroli. 2004b. Un approccio molecolare alla tracciabilità dei prodotti lattiero-caseari caprini. Sci. Tecn. Latt. Cas. 55:251262.

Ceriotti, G., D. Marletta, A. Caroli, and G. Erhardt. 2004a. Milk protein loci in taurine (Bos taurus) and zebu (Bos indicus) populations bred in hot climate. J. Anim. Breed. Genet. 121:404-415.

Chatchatee, P., K. M. Jarvinen, L. Bardina, K. Beyer, and H. A. Sampson. 2001a. Identification of IgE- and IgG-binding epitopes on alpha(s1)-casein: Differences in patients with persistent and transient cow's milk allergy. J. Allergy Clin. Immunol. 107:379383.

Chatchatee, P., K. M. Jarvinen, L. Bardina, L. Vila, K. Beyer, and H. A. Sampson. 2001b. Identification of IgE and IgG binding epitopes on beta- and kappa-casein in cow's milk allergic patients. Clin. Exp. Allergy 31:1256-1262.

Chen, S. Y., V. Costa, M. Azevedo, M. Baig, N. Malmakov, G. Luikart, G. Erhardt, and A. Beja-Pereira. 2008. Short communication: New alleles of the bovine kappa-casein gene revealed by resequencing and haplotype inference analysis. J. Dairy Sci. 91:3682-3686.

Chessa, S., E. Budelli, A. Caroli, and E. Pieragostini. 2003. Variabilità delle lattoproteine nella specie ovina: Stato dell'arte e prospettive. Sci. Tecn. Latt. Cas. 54:35-43.

Chessa, S., F. Chiatti, G. Ceriotti, A. Caroli, C. Consolandi, G. Pagnacco, and B. Castiglioni. 2007. Development of a SNP genotyping microarray platform for the identification of bovine milk protein genetic polymorphisms. J. Dairy Sci. 90:451-464.

Chessa, S., F. Chiatti, D. Rignanese, G. Ceriotti, A. M. Caroli, and G. Pagnacco. 2008a. Analisi in silico delle sequenze caseiniche caprine. Sci. Tecn. Latt. Cas. 59:71-79.

Chessa, S., D. Rignanese, J. Küpper, G. Pagnacco, G. Erhardt, and A. Caroli. 2008b. Short communication: The $\beta$-casein (CSN2) silent allele $C 1$ is highly spread in goat breeds. J. Dairy Sci. 91:44334436.

Chiatti, F., S. Chessa, P. Bolla, G. Cigalino, A. Caroli, and G. Pagnacco. 2007. Effect of k-casein polymorphism on milk composition in Orobica goat. J. Dairy Sci. 90:1962-1966.

Comin, A., M. Cassandro, S. Chessa, M. Ojala, R. Dal Zotto, M. De Marchi, P. Carnier, L. Gallo, G. Pagnacco, and G. Bittante. 2008. Effects of composite $\beta$ - and $\kappa$-casein genotypes on milk coagulation, quality, and yield traits in Italian Holstein cows. J. Dairy Sci. 91:4022-4027.

Crittenden, R. G., and L. E. Bennett. 2005. Cow's milk allergy: A complex disorder. J. Am. Coll. Nutr. 24:582S-591S.

Damiani, G., E. Budelli, S. Florio, A. Caroli, and G. Pagnacco. 2000a. Polymorphism of $\kappa$-casein SINE Bov-A2 and CYP21-hydroxylase in some bovine breeds. Zoot. Nutr. Anim. 3:145-148.

Damiani, G., A. Caroli, P. Leone, E. Budelli, and S. Florio. 2001. Effect of Bov-A2 Sine elements on quantitative traits. Pages 49-51 in Proc. XIV Natl. Congr. ASPA, Florence, Italy. University of Florence Press, Florence, Italy.

Damiani, G., L. Ferretti, G. Rognoni, and V. Sgaramella. 1990 Restriction fragment length polymorphism analysis of the kappacasein locus in cattle. Anim. Genet. 21:107-114.

Damiani, G., S. Florio, E. Budelli, P. Bolla, and A. Caroli. 2000b. Single nucleotide polymorphisms (SNPs) within Bov-A2 SINE in the second intron of bovine and buffalo $\kappa$-casein (CSN3) gene. Anim. Genet. 31:277-279

Damiani, G., F. Pilla, P. Leone, and S. Cacciò. 1992. Direct sequencing and bidirectional allele specific polymerase chain reaction of the bovine beta-casein B variant. Anim. Genet. 23:561-565.
David, V. A., and A. H. Deutch. 1992. Detection of bovine $\alpha_{\mathrm{s} 1^{-}}$ casein genomic variants using the allele-specific polymerase chain reaction. Anim. Genet. 23:425-429.

Di Stasio, L., and P. Mariani. 2000. The role of protein polymorphism in the genetic improvement of milk production. Zoot. Nutr. Anim. 26:69-90.

Di Stasio, L., and P. Merlin. 1979. Polimorfismi biochimici del latte nella razza bovina Grigio Alpina. Riv. Zoot. Vet. 2:64-67.

EFSA (European Food Safety Authority). 2004. Opinion of the Scientific Panel on Dietetic Products, Nutrition and Allergies on a request from the Commission relating to the evaluation of goats' milk protein as a protein source for infant formulae and follow-on formulae. EFSA J. 30:1-15.

EFSA (European Food Safety Authority). 2009. Review of the potential health impact of $\beta$-casomorphins and related peptides. EFSA Sci. Rep. 231:1-107.

Elliott, R. B., D. P. Harris, J. P. Hill, N. J. Bibby, and H. E. Wasmuth 1999. Type I (insulin-dependent) diabetes mellitus and cow milk: Casein variant consumption. Diabetologia 42:292-296.

Erhardt, G. 1996. Detection of a new $\kappa$-casein variant in the milk of Pinzgauer cattle. Anim. Genet. 27:105-107.

Erhardt, G., and A. Eggen. 1990. Untersuchungsmöglichkeiten der Milchproteine mittels Protein- und DNS-Analyse und deren Bedeutung bei züchterischen Fragestellungen. Landwirtschaft Schweiz 3:181-186.

Erhardt, G., E. M. Prinzenberg, J. Buchberger, H. Krick-Saleck, I. Krause, and M. Miller. 1997. Bovine k-casein G detection, occurrence, molecular genetic characterization, genotyping and coagulation properties. Pages 328-329 in Proc. IDF "Milk Protein Polymorphism Seminar II." International Dairy Federation, Brussels, Belgium.

Erhardt, G., and B. Senft. 1991. Nutzungsmöglichkeiten der genetisch bedingten Varianten der Rindermilch im Rahmen der Milchleistungsprüfung. Pages 20-22 in Performance Recording of Animals: State of the Art, 1990. P. Gaillon and Y. Chabert, ed. Springer Netherlands, Pudoc, Wageningen, the Netherlands.

Farrell, H. M. Jr., R. Jimenez-Flores, G. T. Bleck, E. M. Brown, J. E. Butler, L. K. Creamer, C. L. Hicks, C. M. Hollar, K. F. Ng-KwaiHang, and H. E. Swaisgood. 2004. Nomenclature of the proteins of cows' milk-Sixth revision. J. Dairy Sci. 87:1641-1674.

Ferretti, L., P. Leone, and V. Sgaramella. 1990. Long range restriction analysis of the bovine casein genes. Nucleic Acids Res. 18:6829 6833

Fitzgerald, R. J. 1998. Potential uses of caseinophosphopeptides. Int. Dairy J. 8:451-457.

Fitzgerald, R. J., and B. A. Murray. 2006. Bioactive peptides and lactic fermentations . Int. J. Dairy Technol. 59:118-125.

Folch, J. M., P. Dovč, and J. F. Medrano. 1999. Differential expression of bovine $\beta$-lactoglobulin A and B promoter variants in transiently transfected HC11 cells. J. Dairy Res. 66:537-544.

Formaggioni, P., A. Summer, M. Malacarne, and P. Mariani. 1999. Milk protein polymorphism: Detection and diffusion of the genetic variants in Bos genus. Ann. Fac. Med. Vet. Un. Parma. XIX:127165.

Freyer, G., Z. Liu, G. Erhardt, and L. Panicke. 1999. Casein polymorphism and relation between milk production traits. J. Anim. Breed. Genet. 116:87-97.

Ganai, N. A., H. Bovenhuis, J. A. M. van Arendonk, and M. H. P. W. Visker. 2008. Novel polymorphisms in the bovine $\beta$-lactoglobulin gene and their effects on $\beta$-lactoglobulin protein concentration in milk. Anim. Genet. 40:127-133.

Gatesy, J., C. Hayashi, M. A. Cronin, and P. Arctander. 1996. Evidence from milk casein genes that cetaceans are close relatives of hippopotamid artiodactyls. Mol. Biol. Evol. 13:954-963.

Gorodetskiî, S. I., and A. S. Kaledin. 1987. Nucleotide sequence of the cDNA of kappa casein in cows. Genetika 23:596-604.

Grosclaude, F. 1988. Le polymorphisme génétique des principales lactoprotéines bovines. Relations avec la quantité, la composition et les aptitudes fromagères du lait. INRA Prod. Anim. 1:5-17. 
Han, S. K., Y. C. Shin, and H. D. Byun. 2000. Biochemical, molecular and physiological characterization of a new $\beta$-casein variant detected in Korean cattle. Anim. Genet. 31:49-51.

Hartwig, A., H. Teschemacher, W. Lehmann, M. Gauly, and G. Erhardt. 1997. Influence of genetic polymorphism in bovine milk on the occurrence of bioactive peptides. Pages 459-460 in Proc. IDF "Milk Protein Polymorphism Seminar II." International Dairy Federation, Brussels, Belgium..

Hayes, H., and E. Petit. 1993. Mapping of the $\beta$-lactoglobulin gene and of an immunoglobulin $\mathrm{M}$ heavy chain-like sequence in homologous cattle, sheep, and goat chromosomes. Mamm. Genome 4:207210.

Hayes, H., E. Petit, C. Bouniol, and P. Popescu. 1993. Localisation of the alpha-S2-casein gene (CASAS2) to the homologous cattle, sheep and goat chromosome 4 by in situ hybridisation. Cytogenet. Cell Genet. 64:282-285.

Heck, J. M. L., A. Schennink, H. J. F. van Valenberg, H. Bovenhuis, M. H. P. W. Visker, J. A. M. van Arendonk, and A. C. M. van Hooijdonk. 2009. Effects of milk protein variants on the protein composition of bovine milk. J. Dairy Sci. 92:1192-1202.

Hernández-Ledesma, B., L. Amigo, M. Ramos, and I. Recio. 2004. Angiotensin converting enzyme inhibitory activity in commercial fermented products: Formation of peptides under simulated gastrointestinal digestion. J. Agric. Food Chem. 52:1504-1510.

Ibeagha-Awemu, E. M., P. Kgwatalala, and X. Zhao. 2008. A critical analysis of production-associated DNA polymorphisms in the genes of cattle, goat, sheep, and pig. Mamm. Genome 19:591-617.

Ibeagha-Awemu, E. M., E.-M. Prinzenberg, O. C. Jann, G. Lühken, A. E. Ibeagha, X. Zhao, and G. Erhardt. 2007. Molecular characterization of bovine CSN1S2B and extensive distribution of zebu specific milk protein alleles in European cattle. J. Dairy Sci. 90:3522-3529.

Ikonen, T., H. Bovenhuis, M. Ojala, O. Ruottinen, and M. Georges. 2001. Associations between casein haplotypes and first lactation milk production traits in Finnish Ayrshire cows. J. Dairy Sci. 84:507-514.

Jann, O., G. Ceriotti, A. Caroli, and G. Erhardt. 2002b. A new variant in exon VII of bovine $\beta$-casein gene (CSN2) and its distribution among European cattle breeds. J. Anim. Breed. Genet. 119:6568.

Jann, O., E. Ibeagha-Awemu, C. Özbeyaz, P. Zaragoza, J. L. Williams, P. Ajmone-Marsan, J. A. Lenstra, K. Moazami-Goudarzi, and G. Erhardt. 2004. Geographic distribution of haplotype diversity at the bovine casein locus. Genet. Sel. Evol. 36:243-257.

Jann, O., E.-M. Prinzenberg, H. Brandt, J. L. Williams, P. AjmoneMarsan, P. Zaragoza, C. Ozbeyaz, and G. Erhardt. 2002a. Intragenic haplotypes at the bovine CSN1S1 locus. Arch. Tierz. $45: 13-21$

Kim, J. S., M. Braunschweig, and Z. Puhan. 1996. Occurrence of extreme ratio of $\beta$-lactoglobulin variants $\mathrm{A}$ and $\mathrm{B}$ in Swiss Brown cattle quantified by capillary electrophoresis. Milchwissenschaft 51:435-438.

Kitts, D. D., and K. Weiler. 2003. Bioactive proteins and peptides from food sources: Applications of bioprocesses used in isolation and recovery. Curr. Pharm. Des. 9:1309-1323.

Knivsber, A. M., K. L. Reichelt, and M. Nodland. 2001. Reports on dietary intervention in autistic disorders. Nutr. Neurosci. 4:2537.

Korhonen, H., and A. Pihlanto. 2006. Bioactive peptides: Production and functionality. Int. Dairy J. 16:945-960.

Krause, I., J. Buchberger, G. Weiß, and H. Klostermeyer. 1988. Screening methods for genetic variants of milk proteins. Pages 171-173 in Milk Proteins: Nutritional, Clinical, Functional and Technological Aspects. C. A. Barth and E. Schlimme, ed. Steinkopff Verlag, Darmstadt, Germany.

Kühn, C., G. Freyer, R. Weikard, T. Goldammer, and M. Schwerin. 1999. Detection of QTL for milk production traits in cattle by application of a specifically developed markermap of BTA6. Anim. Genet. 30:333-340.

Lemay, D. G., D. J. Lynn, W. F. Martin, M. C. Neville, T. M. Casey, G. Rincon, E. V. Kriventseva, W. C. Barris, A. S. Hinrichs, A.
J. Molenaar, K. S. Pollard, N. J. Maqbool, K. Singh, R. Murney, E. M. Zdobnov, R. L. Tellam, J. F. Medrano, J. B. German, and M. Rijnkels. 2009. The bovine lactation genome: Insights into the evolution of mammalian milk. Genome Biol. 10:R43.

Lien, S., L. Gomez-Raya, T. Steine, E. Fimland, and S. Rogne. 1995. Associations between casein haplotypes and milk yield traits. J. Dairy Sci. 78:2047-2056.

Lien, S., J. Kantanen, I. Olsaker, L. E. Holm, E. Eythorsdottir, K. Sandberg, B. Dalsgaid, and S. Adalsteinsson. 1999. Comparison of milk protein allele frequencies in Nordic cattle breeds. Anim. Genet. 30:85-91.

Lien, S., and S. Rogne. 1993. Bovine casein haplotypes: Number, frequencies and applicability as genetic markers. Anim. Genet. $24: 373-376$.

Lisson, M., and G. Erhardt. 2008. Allergenic potential of bovine milk proteins with regards to genetic variants. Invited seminar. University of Brescia, Brescia, Italy.

Lorenzini, E., S. Chessa, F. Chiatti, A. Caroli, and G. Pagnacco. 2007. Peptidi bioattivi di latte e derivati. Sci. Tecn. Latt. Cas. 58:113156

Losi, G., G. B. Castagnetti, L. Grazia, C. Zambonetti, P. Mariani, and V. Russo. 1973. Influenza delle varianti genetiche della caseina $\kappa$ sulla formazione e sulle caratteristiche della cagliata. Sci. Tech. Alim. 3:373-374.

Lühken, G., A. Caroli, E. M. Ibeagha-Awemu, and G. Erhardt. 2009. Characterization and genetic analysis of bovine $\alpha_{\mathrm{s} 1}$-casein I variant. Anim. Genet. 40:479-485.

Lum, L. S., P. Dovč, and J. F. Medrano. 1997. Polymorphisms of bovine $\beta$-lactoglobulin promoter and differences in the binding affinity of activator protein-2 transcription factor. J. Dairy Sci. 80:1389-1397.

Mahé, M. F., G. Miranda, R. Queval, A. Bado, P. S. Zafindrajona, and F. Grosclaude. 1999. Genetic polymorphism of milk proteins in African Bos taurus and Bos indicus populations: Characterization of variants $\alpha_{\mathrm{s} 1}-\mathrm{Cn} \mathrm{H}$ and $\kappa-\mathrm{Cn}$ J. Genet. Sel. Evol. 31:239-253.

Malkoski, M., S. G. Dashper, N. M. O'Brien-Simpson, G. H. Talbo, M. Macris, K. J. Cross, and E. C. Reynolds. 2001. Kappacin, a novel antibacterial peptide from bovine milk. Antimicrob. Agents Chemother. 45:2309-2315.

Mariani, P. 1983. Sulla presenza di una terza k-caseina nel latte di vacche di razza Bruna. Sci. Tecn. Latt. Cas. 34:174-181.

Mariani, P., G. Losi, V. Russo, G. B. Castagnetti, L. Grazia, D. Morini, and E. Fossa. 1976. Prove di caseificazione con latte caratterizzato dalle varianti A e B delle $\kappa$-caseina nella produzione del formaggio Parmigiano-Reggiano. Sci. Tecn. Latt. Cas. 27:208-227.

Martin, P., M. Szymanowska, L. Zwierzchowski, and C. Leroux. 2002. The impact of genetic polymorphisms on the protein composition of ruminants milks. Reprod. Nutr. Dev. 42:433-459.

McLachlan, C. N. 2001. Beta-casein A1, ischaemic heart disease mortality, and other illnesses. Med. Hypotheses 56:262-272.

Medrano, J. F., and E. Aguilar-Cordova. 1990. Polymerase chain reaction amplification of bovine $\beta$-lactoglobulin genomic sequences and identification of genetic variants by RFLP analysis. Anim. Biotechnol. 1:73-77.

Meisel, H. 1998. Overview on milk protein derived peptides. Int. Dairy J. 8:363-373.

Mercier, J.-C., G. Brignon, and B. Ribadeau-Dumas. 1973. Structure primarie de la caseine $\kappa$-bovine B. Sequence complete. Eur. J. Biochem. 35:222-235.

Mercier, J.-C., J. M. Chobert, and F. Addeo. 1976. Comparative analysis of the amino acid sequences of caseinomacropeptides from seven species. FEBS Lett. 72:208-214.

Mercier, J. C., and J. L. Vilotte. 1993. Structure and function of milk protein genes. J. Dairy Sci. 76:3079-3098.

Miranda, G., P. Anglade, M. F. Mahé, and G. Erhardt. 1993. Biochemical characterization of the bovine genetic k-casein $\mathrm{C}$ and E variants. Anim. Genet. 24:27-31.

Moazami-Goudarzi, K., D. M. A. Belemsaga, G. Ceriotti, D. Laloë, F. Fagbohoun, N'T. Kouagou, I. Sidibè, V. Codjia, C. Crimella, F. Grosclaude, and S. M. Tourè. 2001. Caractérisation de la race 
bovine Somba à l'aide de marqueurs molécolaires. Rev. Elev. Med. Vet. Pays Trop. 54:129-138.

Mohr, U., D. Koczan, D. Linder, G. Hobom, and G. Erhardt. 1994. A single point mutation results in A allele-specific exon skipping in the bovine $\alpha_{S 1}$-casein mRNA. Gene 143:187-192.

Nilsen, H., H. G. Olsen, B. Hayes, E. Sehested, M. Svendsen, T. Nome, T. Meuwissen, and S. Lien. 2009. Casein haplotypes and their association with milk production traits in Norwegian Red cattle. Genet. Sel. Evol. 41:24.

Olsen, H. G., S. Lien, M. Gautier, H. Nilsen, A. Roseth, P. R. Berg, K. K. Sundsaasen, M. Svendsen, and T. H. E. Meuwissen. 2005. Mapping of a milk production quantitative trait locus to a $420-\mathrm{kb}$ region on bovine chromosome 6. Genetics 169:275-283.

Popescu, C. P., S. Long, P. Riggs, J. Womack, S. Schmutz, R. Fries, and D. S. Gallagher. 1996. Standardization of cattle karyotype nomenclature: Report of the committee for the standardization of the cattle karyotype. Cytogenet. Cell Genet. 74:259-261.

Prinzenberg, E.-M., S. Hiendleder, T. Ikonen, and G. Erhardt. 1996. Molecular genetic characterization of new bovine $\kappa$-casein alleles CSN3-F and CSN3-G and genotyping by PCR-RFLP. Anim. Genet. 27:347-349.

Prinzenberg, E.-M., H. Jianlin, and G. Erhardt. 2008. Genetic variation in the $\kappa$-casein gene (CSN3) of chinese yak (Bos grunniens) and phylogenetic analysis of CSN3 sequences in the genus Bos. J. Dairy Sci. 91:1198-1203.

Prinzenberg, E. M., I. Krause, and G. Erhardt. 1999. SSCP analysis at the bovine CSN3 locus discriminates six alleles corresponding to known protein variants $(A, B, C, E, F, G)$ and 3 new DNA polymorphisms $\left(H, I, A^{I}\right)$. Anim. Biotechnol. 10:49-62.

Prinzenberg, E. M., C. Weimann, H. Brandt, J. Bennewitz, E. Kalm, M. Schwerin, and G. Erhardt. 2003. Polymorphism of the bovine CSN1S1 promoter: Linkage mapping, intragenic haplotypes, and effect on milk production traits. J. Dairy Sci. 86:2696-2705.

Rando, A., P. Di Gregorio, L. Ramunno, P. Mariani, A. Fiorella, C. Senese, D. Marletta, and P. Masina. 1998. Characterization of the $\mathrm{CSN}_{1} \mathrm{~A}^{\mathrm{G}}$ allele of the bovine $\alpha_{\mathrm{s} 1}$-casein locus by the insertion of a relict of a long interspersed element. J. Dairy Sci. 81:1735-1742.

Rando, A., L. Ramunno, and P. Masina. 2000. Mutations in casein genes. Zoot. Nutr. Anim. 26:105-114.

Rijnkels, M. 2002. Multispecies comparison of the casein gene loci and evolution of casein gene family. J. Mammary Gland Biol. Neoplasia 7:327-345.

Schlieben, S., G. Erhardt, and B. Senft. 1991. Genotyping of bovine $\kappa$-casein $\left(\kappa-\mathrm{CN}^{\mathrm{A}}, \kappa-\mathrm{CN}^{\mathrm{B}}, \kappa-\mathrm{CN}^{\mathrm{C}}, \kappa-\mathrm{CN}^{\mathrm{E}}\right)$ following DNA sequence amplification and direct sequencing of $\kappa-\mathrm{CN}^{\mathrm{E}} \mathrm{PCR}$ product. Anim. Genet. 22:333-342.

Schopen, G. C. B., P. D. Koks, J. A. M. van Arendonk, H. Bovenhuis, and M. H. P. W. Visker. 2009. Whole genome scan to detect quantitative trait loci for bovine milk protein composition. Anim. Genet. 40:524-537.

Seibert, B., G. Erhardt, and B. Senft. 1987. Detection of a new k-casein variant in cow's milk. Anim. Genet. 18:269-272.

Senocq, D., D. Mollé, S. Pochet, J. Léonil, D. Dupont, and D. Levieux. 2002. A new bovine $\beta$-casein genetic variant characterized by a Met93 > Leu93 substitution in the sequence $A^{2}$. Lait 82:171180.

Sulimova, G. E., I. N. Badagueva, and I. G. Udina. 1996. Polymorphism of the $\kappa$-casein gene in subfamilies of the Bovidae. Genetika (Moskva) 32:1576-1582.

Sulimova, G. E., S. S. Sokolova, O. P. Semikozova, L. M. Nguet, and E. M. Berberov. 1992. Analysis of DNA polymorphisms of clustered genes in cattle: Casein genes and genes of the major histocompatibility complex (BOLA). Tsitol. I Genetika 26:1826.

Sun, Z., Z. Zhang, X. Wang, R. Cade, Z. Elmir, and M. Fregly. 2003. Relation of beta-casomorphin to apnea in sudden infant death syndrome. Peptides 24:937-943.

Threadgill, D. W., and J. E. Womack. 1990. Genomic analysis of the major bovine milk proteins genes. Nucleic Acids Res. 18:69356942.

Velmala, R. J., H. J. Vilkki, K. T. Elo, D. J. de Koning, and A. V. Mäki-Tanila. 1999. A search for quantitative trait loci for milk production traits on chromosome 6 in Finnish Ayrshire cattle. Anim. Genet. 30:136-143.

Voelker, G. R., G. T. Bleck, and M. B. Wheeler. 1997. Single-base polymorphisms within the $5^{\prime}$-flanking region of the bovine Q-lactalbumin gene. J. Dairy Sci. 80:194-197.

Wagner, V., T. Schild, and H. Geldermann. 1994. DNA variants within the 5 -flanking regions of milk protein genes. II. The $\beta$-lactoglobulinencoding gene. Theor. Appl. Genet. 89:121-126.

Wal, J. M. 2004. Bovine milk allergenicity. Ann. Allergy Asthma Immunol. 93:2-11.

Ward, T. J., R. L. Honeycutt, and J. N. Derr. 1997. Nucleotide sequence evolution at the kappa-casein locus: Evidence for positive selection within the family Bovidae. Genetics 147:1863-1872.

Weimann, C., H. Meisel, and G. Erhardt. 2009. Short communication: Bovine $\kappa$-casein variants result in different angiotensin I converting enzyme (ACE) inhibitory peptides. J. Dairy Sci. 92:1885-1888. 